\title{
Relating CCN activity, volatility, and droplet growth kinetics of $\beta$-caryophyllene secondary organic aerosol
}

\author{
A. Asa-Awuku ${ }^{1, *}$, G. J. Engelhart ${ }^{2}$, B. H. Lee ${ }^{2}$, S. N. Pandis ${ }^{2,3}$, and A. Nenes ${ }^{1,4}$ \\ ${ }^{1}$ School of Chemical and Biomolecular Engineering, Georgia Institute of Technology, Atlanta, GA, USA \\ ${ }^{2}$ Department of Chemical Engineering, Carnegie Mellon University, Pittsburgh, PA, USA \\ ${ }^{3}$ Department of Chemical Engineering, University of Patras, Patra, Greece \\ ${ }^{4}$ School of Earth and Atmospheric Sciences, Georgia Institute of Technology, Atlanta, GA, USA \\ *currently at: Dept. of Chemical and Environmental Engineering, University of California Riverside, Riverside, CA, USA
}

Received: 15 April 2008 - Published in Atmos. Chem. Phys. Discuss.: 30 May 2008

Revised: 16 December 2008 - Accepted: 16 December 2008 - Published: 2 February 2009

\begin{abstract}
This study investigates the droplet formation characteristics of secondary organic aerosol (SOA) formed during the ozonolysis of sesquiterpene $\beta$-caryophyllene (with and without hydroxyl radicals present). Emphasis is placed on understanding the role of semi-volatile material on Cloud Condensation Nucleus (CCN) activity and droplet growth kinetics. Aging of $\beta$-caryophyllene SOA significantly affects all $\mathrm{CCN}$-relevant properties measured throughout the experiments. Using a thermodenuder and two CCN instruments, we find that $\mathrm{CCN}$ activity is a strong function of temperature (activation diameter at $\sim 0.6 \%$ supersaturation: $100 \pm 10 \mathrm{~nm}$ at $20^{\circ} \mathrm{C}$ and $130 \pm 10 \mathrm{~nm}$ at $35^{\circ} \mathrm{C}$ ), suggesting that the hygroscopic fraction of the SOA is volatile. The water-soluble organic carbon (WSOC) is extracted from the SOA and characterized with Köhler Theory Analysis (KTA); the results suggest that the WSOC is composed of low molecular weight $\left(<200 \mathrm{~g} \mathrm{~mol}^{-1}\right)$ slightly surface-active material that constitute $5-15 \%$ of the SOA mass. These properties are similar to the water-soluble fraction of monoterpene SOA, suggesting that predictive understanding of SOA CCN activity requires knowledge of the WSOC fraction but not its exact speciation. Droplet growth kinetics of the $\mathrm{CCN}$ are found to be strongly anticorrelated with WSOC fraction, suggesting that the insoluble material in the SOA forms a kinetic barrier that delays droplet growth. Overall, volatilization effects can increase activation diameters by $30 \%$, and depress droplet growth rate by a factor of two; these results may have important impli-
\end{abstract}

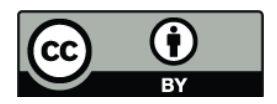

Correspondence to: A. Nenes (nenes@eas.gatech.edu) cations for the droplet formation characteristics of SOA, and the atmospheric relevance of $\mathrm{CCN}$ measurements carried out at temperatures different from ambient.

\section{Introduction}

Secondary organic aerosol (SOA) particles have the potential to impact climate and the hydrological cycle (the socalled aerosol indirect effect) through their ability to act as cloud condensation nuclei (CCN). Carbonaceous material can comprise up to $90 \%$ of the aerosol mass (Andreae and Crutzen, 1997; Cachier et al., 1995; Yamasoe et al., 2000), a significant fraction of which may dissolve in water (watersoluble organic carbon; WSOC) (Kanakidou et al., 2005; Sullivan et al., 2004; Decesari et al., 2000; Zappoli et al., 1999). Studies have shown that WSOC can influence hygroscopicity, surface tension, and possibly, droplet growth kinetics (e.g. Decesari et al., 2003; Saxena et al., 1995; Shulman et al., 1996) and must be characterized to quantify the impact of aerosol on cloud droplet formation and reduce uncertainties associated with the aerosol indirect effect.

The WSOC fraction of CCN may originate from primary emissions or form during the oxidation of volatile organic compounds (VOC) (Kanakidou et al., 2005; Robinson et al., 2007; Saxena and Hildemann, 1996). Natural VOC emissions (e.g. monoterpernes and sesquiterpenes) are estimated to be on the order of $1150 \mathrm{Tg} \mathrm{yr}^{-1}$ (Guenther et al., 1995), and are thought to dominate anthropogenic emissions (Guenther et al., 1999, 2000; Kanakidou et al., 2005). The resulting SOA can contribute significantly to the atmospheric

Published by Copernicus Publications on behalf of the European Geosciences Union. 
organic particulate mass (Donahue et al., 2005; Kanakidou et al., 2005; Odum et al., 1996; Pathak et al., 2007; Robinson et al., 2007; Seinfeld and Pankow, 2003; Stanier et al., 2007; Volkamer et al., 2006; Zhang et al., 2007) and become more hygroscopic during the aging process (Kanakidou et al., 2005; Rudich, 2003) hence contributing significant amounts of WSOC. However relatively little is known about the chemical composition of SOA (Rogge et al., 1993; Seinfeld and Pandis, 1998; Kalberer, 2006) and as a consequence, the $\mathrm{CCN}$-relevant thermodynamic properties (solubility, molecular weight, surfactant characteristics) and droplet growth kinetics of organic aerosol have remained elusive (Kanakidou et al., 2005).

The hygroscopicity of SOA has been studied for a series of parent hydrocarbons and oxidation conditions (e.g. Varutbangkul et al., 2006, and references therein). SOA produced from seedless monoterpene ozonolysis, such as $\alpha$-pinene, has been the focus of numerous studies (Engelhart et al., 2008; Huff-Hartz et al., 2005; Saathoff et al., 2003; Prenni et al., 2007; VanReken et al., 2005; Virkkula et al., 1999); most find that the SOA is hygrosocopic and $\mathrm{CCN}$ active, but less than $\left(\mathrm{NH}_{4}\right)_{2} \mathrm{SO}_{4}$. VanReken et al. (2005) showed $\mathrm{CCN}$ activity dependence on the monoterpene SOA precursor, whereas Prenni et al. (2007) and Engelhart et al. (2008) do not; in fact, the latter two studies show that a rather wide variety of monoterpene SOA exhibit very similar CCN properties. Aging of aerosol is often associated with an increase in hygroscopicity (CCN activity), although this may not always be the case (Varutbangkul et al., 2006; VanReken et al., 2005). Decreases in hygroscopicity are often attributed to the formation of oligomers that deplete the SOA from soluble monomers (Varutbangkul et al., 2006; VanReken et al., 2005). Polymeric (i.e., high molecular weight) material tends to be less-hygroscopic and nonvolatile (Baltensperger et al., 2005; Kalberer et al., 2004; Reynolds et al., 2006) and often exhibits characteristics similar to HUmic-LIke Substances (HULIS) (Baltensperger et al., 2005).

Though not studied to the same extent as monoterpenes, sesquiterpenes are an important class of parent hydrocarbons because of their high aerosol yields (Griffin et al., 1999a,b) and widespread emission from more than forty vegetation species in abundance (Arey et al., 1995; Hansen and Seufert, 2003; Helmig et al., 2007; Hoffmann, 1995; Konig et al., 1995; Zhang et al., 1999). $\beta$-caryophyllene is one of the most reactive and abundant sesquiterpenes (Ciccioli et al., 1999; Goldstein and Galbally, 2007; Hansen and Seufert, 2003; Helmig et al., 2007; Jaoui et al., 2007; Grosjean et al., 1993; Shu and Atkinson, 1994; Kanawati et al., 2008). Due to the high molecular weight (low volatility) of its oxidation products, $\beta$-caryophyllene produces high aerosol yields in SOA chamber experiments, as large as $70 \%$ (Lee et al., 2006), and can be an important $\mathrm{PM}_{2.5}$ contributor in the Southeastern United States (Jaoui et al., 2007; Kleindienst et al., 2007) and in boreal forests (Parshintsev et al., 2008). The main aerosol phase products of dark seedless $\beta$-caryophyllene ozonolysis are two semi-volatile ketoaldehydes; 3,3-dimethyl-y-methylene2-(3-oxo-butyl)-cyclobutanebutanal $\quad(\beta$-caryophyllone aldehyde, $236 \mathrm{~g} \mathrm{~mol}^{-1}$ ) and 3,3-dimethyl-y-oxo-2- (3oxobutyl)-cyclobutanebutanal ( $\beta$-nocaryophyllone aldehyde, $238 \mathrm{~g} \mathrm{~mol}^{-1}$; Calogirou et al. (1997); Jaoui et al. (2003)). These compounds exhibit low volatility and can readily form aerosol. Jaoui et al. (2003) presented the most comprehensive $\beta$-caryophyllene ozonolysis speciation so far, identifying 17 compounds in both the gas and aerosol phases for a combined carbon yield of 65\%; based on these studies, the mass-average molecular weight of the SOA is estimated to be $250 \mathrm{~g} \mathrm{~mol}^{-1}$ (Huff-Hartz et al., 2005).

The aerosol formed during $\beta$-caryophyllene ozonolysis can act as CCN (Donahue et al., 2005; Huff-Hartz et al., 2005; Varutbangkul et al., 2006) yet SOA from sesquiterpenes are less hygroscopic and $\mathrm{CCN}$-active than monoterpene SOA (Huff-Hartz et al., 2005; Varutbangkul et al., 2006). Varutbangkul et al. (2006) observed the hygroscopicity of $\beta$-caryophyllene SOA to decrease with aging. Predicting the $\mathrm{CCN}$ activity of the SOA requires assumptions for its solubility and surfactant characteristics. Huff-Hartz et al. (2005) used an "effective solubility" (i.e. one common solubility for all compounds present in the SOA), which ranges around $0.10 \mathrm{~g} \mathrm{~g}^{-1} \mathrm{H}_{2} \mathrm{O}$ for monoterpene and sesquiterpene SOA; other studies assume complete solubility of the SOA (e.g. Prenni et al., 2007). Surface tension at the point of activation is often assumed to be equal to that of water, although recent studies relax this assumption (Cai and Griffin, 2005; Engelhart et al., 2008; Shilling et al., 2007; Asa-Awuku et al., 2007). Even if the usage of simplifying assumptions for thermodynamic properties (e.g. complete solubility and constant surface tension) reproduces the measured $\mathrm{CCN}$ activity, this does not imply that they reflect the true properties of the aerosol (Engelhart et al., 2008).

There is currently little work on the link between SOA volatility and $\mathrm{CCN}$ activity and the potential effect of semivolatile organic compounds on aerosol hygroscopicity and CCN properties (An et al., 2007; Baltensperger et al., 2005; Jonsson et al., 2007; Kanakidou et al., 2005). The volatility of VOC oxidation products largely control their gas-toparticle partitioning (Pankow, 1994), and if water-soluble, also their CCN activity. Chamber and ambient studies have measured the volatility for aging SOA (e.g. An et al., 2007; Baltensperger et al., 2005; Grieshop et al., 2007; Kalberer et al., 2004), coupled with hygroscopicity measurements (Fletcher et al., 2007; Johnson et al., 2005; Jonsson et al., 2007; Tomlinson et al., 2007). Results suggest that SOA formed by $\mathrm{OH}$ oxidation is more volatile than the SOA formed during reactions with other oxidants (e.g. $\mathrm{O}_{3}$ ) (Jonsson et al., 2007). Although the hygroscopic water uptake measured for SOA below water saturation may not accurately reflect their CCN activity (Prenni et al., 2007), the hygroscopicity of the organic material may resemble that of $\left(\mathrm{NH}_{4}\right)_{2} \mathrm{SO}_{4}$ (Fletcher et al., 2007). 


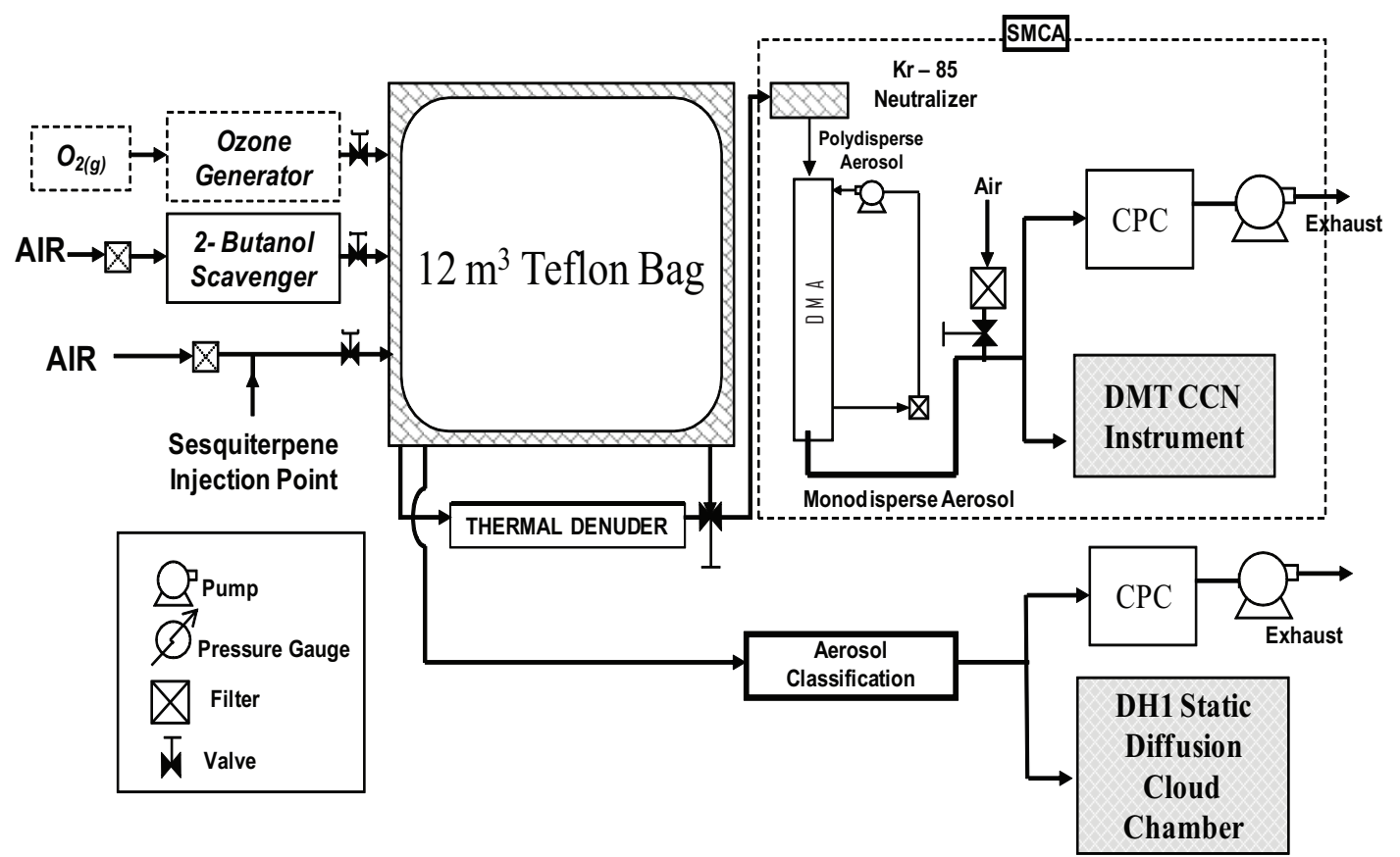

Fig. 1. Experimental set-up for SOA generation and online analysis.

An important aspect of droplet formation that is largely unconstrained is the effect of composition on droplet growth kinetics. Complex growth kinetics can arise from numerous mechanisms, such as incomplete solubility (Shulman et al., 1996; Shantz et al., 2003), slow dissolution kinetics of solute (Asa-Awuku and Nenes, 2007), and organic films, all of which can decrease droplet growth rates (a comprehensive discussion on water vapor uptake mechanisms can be found in Pöschl et al., 2007). Such effects can be parameterized in terms of an "effective" water vapor uptake coefficient, $\alpha$, which is used to determine the mass transfer coefficient of water vapor to the growing droplets (Fountoukis and Nenes, 2005). Values of $\alpha \sim 0.042$ were used in early cloud modeling studies for inorganic aerosol (see review in Lance et al., 2004), while recent aerosol-cloud droplet closure studies show a range of $\alpha$ from 0.04 to 1 (McFiggins et al., 2006). Conant et al. (2004), Meskhidze et al. (2005), and Fountoukis et al. (2007) conducted aerosol-cloud droplet closure using in-situ observations of cumuliform and stratiform clouds formed in polluted and clean air masses; all achieved closure for $\alpha$ between 0.03 and 1.0, with optimum estimates (i.e. where average droplet closure error and standard deviation thereof lie within measurement uncertainty) between 0.03 and 0.06. Stroud et al. (2007), using a static diffusion chamber combined with a model of the instrument, estimated $\alpha=0.07$ for ambient biogenic $\mathrm{CCN}$ sampled during the CELTIC experiment. Ruehl et al. (2008), using a continuous flow thermal gradient CCN chamber (Roberts and Nenes, 2005) coupled with a model of the instrument, also infer a wide range of growth kinetics for ambient aerosol sampled in sites across the United States.

In this study we investigate the droplet formation characteristics of aging $\beta$-caryophyllene SOA generated via seedless dark ozonolysis. Employing two different $\mathrm{CCN}$ counters, we comprehensively characterize the $\mathrm{CCN}$ activity and droplet growth kinetics of the SOA, and explore the role of its volatile fraction on droplet formation. From filter samples of SOA obtained during these experiments, surfactant characteristics, average molar volume and droplet growth kinetics of the water-soluble component are determined with Köhler Theory Analysis (KTA) (Asa-Awuku et al., 2007, 2008; Padró et al., 2007). SOA and WSOC measurements are then combined to infer the soluble fraction of SOA, as well as the impacts of chemical aging thereon. Finally, we explore the impact of composition (i.e. insoluble fraction) on droplet growth kinetics, by combining the $\mathrm{CCN}$ activation measurements with comprehensive models of the $\mathrm{CCN}$ instrumentation.

\section{Experimental methods}

\subsection{SOA formation and experiment design}

Experiments in this study were conducted in the Carnegie Mellon University $12 \mathrm{~m}^{3}$ Teflon SOA chamber (Welch Fluorocarbon), suspended inside a temperature-controlled room (Fig. 1). Details of the smog chamber and its operation are reported elsewhere (Presto et al., 2005a,b; Stanier et al., 
Table 1. Experiments carried out in this study.

\begin{tabular}{cccccccc}
\hline $\begin{array}{c}\text { Experiment } \\
\text { Number }\end{array}$ & $\begin{array}{c}\beta \text {-caryophyllene } \\
\text { Concentration }(\mathrm{ppb})\end{array}$ & $\begin{array}{c}\mathrm{O}_{3} \text { Concentration } \\
(\mathrm{ppb})\end{array}$ & $\begin{array}{c}\text { 2-Butanol } \\
\text { Present? }\end{array}$ & $\begin{array}{c}\text { Oxidizing } \\
\text { Agent }\end{array}$ & $\begin{array}{c}\text { TD } \\
\text { Used? }\end{array}$ & $\begin{array}{c}\text { Peak SOA Mass } \\
\left(\mu \mathrm{g} \mathrm{cm}^{-3}\right)\end{array}$ & $\begin{array}{c}\text { CCN } \\
\text { Counter }\end{array}$ \\
\hline 1 & 22 & 300 & Yes & $\mathrm{O}_{3}$ & No & 27 & SD, CFSTGC \\
2 & 28 & 300 & No & $\mathrm{O}_{3}+\mathrm{OH}$ & Yes & 31.8 & SD, CFSTGC \\
$3^{\mathrm{b}}$ & 28 & 300 & Yes & $\mathrm{O}_{3}$ & No & 49.8 & CFSTGC \\
$4^{\mathrm{b}}$ & 22 & 300 & Yes & $\mathrm{O}_{3}$ & No & - & SD \\
5 & 32 & 300 & Yes & $\mathrm{O}_{3}$ & No & - & SD \\
\hline
\end{tabular}

${ }^{\mathrm{a}}$ There is no $\mathrm{OH}$ when 2-Butanol is present, and vice versa; ${ }^{\mathrm{b}}$ Filter collection experiment.

2007). The experiments carried out are summarized in Table 1 ; the SOA was formed in unseeded dark ozonolysis of $\beta$-caryophyllene (Fluka $>+98.5 \%$ ). For each dry chamber experiment, oxidation occurred at $22^{\circ} \mathrm{C}$ at low relative humidity (3-8\%); aerosol measurements commenced after the injection of sesquiterpene and lasted up to $11 \mathrm{~h}$. $0.5 \mathrm{ml}$ of 2-butanol was used as hydroxyl radical $(\mathrm{OH})$ scavenger so oxidation could occur in the presence and absence of $\mathrm{OH}(\mathrm{Ta}-$ ble 1). "Online" measurements of aerosol properties are carried out to characterize the CCN activity of the aging SOA, and its sensitivity to precursor concentration, oxidant type, $\mathrm{CCN}$ instrument and thermal processing (Experiments 1, 2, $4,5)$. The properties of the water-soluble fraction of the SOA is measured "offline" (Experiment 3), using SOA collected upon filters. Experiments were repeated to assure their reproducibility.

\subsection{Online measurements of SOA}

As shown in Fig. 1, the aerosol from the chamber inlet is classified by a scanning mobility particle sizer (SMPS 3080) and differential mobility analyzer (DMA 3081). The total aerosol concentration (CN) of the monodisperse particles is counted by a condensation particle counter (TSI CPC 3010) and the CCN concentration is measured by a DH Associates-M1 Static Diffusion (SD) CCN Counter and a DMT Continuous-Flow Streamwise Thermal Gradient CCN Counter (CFSTGC) (Lance et al., 2006; Roberts and Nenes, 2005). The DMA used with the CFSTGC was operated at a sheath-to-aerosol ratio of 10:1, and at a 17.5:4 flow ratio for the SD.

Experiment 2 (Table 1) focused largely on the relationship between volatility and CCN activity. The SOA was at times passed through a thermodenuder (TD; An et al., 2007) at $35^{\circ} \mathrm{C}$ for $\sim 15 \mathrm{~s}$ before introduction to aerosol classification and CCN measurements. Roughly $20 \%$ of the particle volume evaporated over the course of the experiment. The temporal conditions in the thermodenuder simulate and closely resemble those in the CFSTGC.

The SD CCN counter requires $7.5 \mathrm{~min}$ per datum $(\sim 0.002 \mathrm{~Hz})$; to capture the impacts of aging on $\mathrm{CCN}$ ac- tivity, the SD is operated at $0.60 \% \pm 0.02 \%$ supersaturation in experiments 1 and 2 , and is supplied with $100 \mathrm{~nm}$ diameter classified aerosol. Additional experiments (4 and 5) were performed with the SD counter to estimate the activation diameter, $d$, (i.e. the dry diameter of the aerosol particle with critical supersaturation, $\left.s_{c}\right)$. For these experiments, a similar analysis and set-up (not shown here) to that presented in Cruz and Pandis (1997) are used. Two classifying systems are employed; the first DMA selects a monodiserpse aerosol, and the second DMA scans several sizes and measures the distrbution of particles. The method uses the activated fraction $(\mathrm{CCN} / \mathrm{CN})$ to determine the fraction of particles in each distribution with a diameter greater than $d$.

The CFSTGC is considerably faster $(\sim 1 \mathrm{~Hz})$ than the SD counter, allowing for a comprehensive characterization of size resolved CCN activity using Scanning Mobility CCN Analysis (SMCA) (Nenes and Medina, 2009) which couples the CFSTGC CCN counter with a SMPS. By keeping the CFSTGC supersaturation, $s$, constant during the scanning cycle of the SMPS, we obtain the time series of $\mathrm{CN}$ and $\mathrm{CCN}$ counts; an inversion procedure then leads to the $\mathrm{CCN} / \mathrm{CN}$ ratio as a function of dry mobility diameter. This procedure is repeated over multiple supersaturations, giving a characterization of the size-resolved $\mathrm{CCN}$ properties for a range of supersaturations every $2.25 \mathrm{~min}$. SMCA has been evaluated for calibration, laboratory and ambient aerosol, SOA filter samples, biomass burning aerosol (Asa-Awuku et al., 2007, 2008; Nenes and Medina, 2009; Padró et al., 2007) and monoterpene SOA (Engelhart et al., 2008).

SMCA also provides size-resolved droplet growth measurements as the DMT CCN counter measures, through its optical particle counter (OPC), the droplet size distribution of activated $\mathrm{CCN}$. Aerosol particles, when exposed to the same supersaturation profile, will grow to approximately the same wet diameter, $D_{p}$, provided that the mass transfer coefficient of the water vapor to the growing droplet and the critical supersaturation is the same (Nenes et al., 2001). The dependence of droplet size on the supersaturation profile and particle size can then be used to study the impact of organics on the droplet growth kinetics (Asa-Awuku et al., 2007; Engelhart et al., 2008; Lance et al., 2006; Moore et al., 2008; 
Ruehl et al., 2008). In this study, we focus on droplet sizes of activated SOA particles with $s_{c}$ equal to the instrument supersaturation, as such $\mathrm{CCN}$ tend to have the smallest droplet size, hence are most sensitive to kinetic limitations. Changes in growth kinetics are quantified by $i$ ) comparison against the droplet size attained by $\mathrm{CCN}$ composed of pure $\left(\mathrm{NH}_{4}\right)_{2} \mathrm{SO}_{4}$, and, ii) using comprehensive models of the instruments to infer growth kinetic parameters of the SOA.

The characterization of $s$ in the $\mathrm{CCN}$ instrumentation is done by determining the minimum diameter, $d$, of $\left(\mathrm{NH}_{4}\right)_{2} \mathrm{SO}_{4}$ calibration aerosol that activates for a constant instrument operating temperature difference, $\Delta T$. Calibration aerosol is generated by atomization of an $\left(\mathrm{NH}_{4}\right)_{2} \mathrm{SO}_{4}$ aqueous solution via a collision-type atomizer. The droplet stream was passed through multiple diffusional driers (operating at $\sim 5 \% \mathrm{RH}$ ), resulting in a polydisperse dry aerosol (with modal diameter $\sim 50 \mathrm{~nm}$ ), which is subsequently charged using a Kr-85 neutralizer (TSI 3077A), and, classified using a TSI 3080 Scanning Mobility Particle Sizer (composed of a TSI 3010 condensation particle counter and a TSI 3081 differential mobility analyzer operating under a sheath-to-aerosol ratio of 10:1). The classified aerosol is then concurrently introduced into the CPC and CCN counter to provide an "activation curve" (or ratio of $\mathrm{CCN} / \mathrm{CN}$ over a wide range of sizes). From the activation curves, $d$ is determined as the dry diameter for which $\mathrm{CCN} / \mathrm{CN}=0.5$. $d$ is related to $s$ by applying Köhler theory, assuming that $\left(\mathrm{NH}_{4}\right)_{2} \mathrm{SO}_{4}$ has a density of $1760 \mathrm{~kg} \mathrm{~m}^{-3}$, surface tension of water, molar mass of $0.132 \mathrm{~kg} \mathrm{~mol}^{-1}$ and an effective van't Hoff factor of 2.5 (Gerber et al., 1977; Brechtel and Kreidenweis, 2000; Kumar et al., 2003; Rose et al., 2008). $d$ (and $s$ ) is determined for each CCN instrument over a range of applied $\Delta T$; a linear fit provides an empirical relationship between $\Delta T$ and $s$ which is then subsequently used in the experiments. The standard deviation in the supersaturation was determined from the standard deviation observed in $d$. SMCA is used for determining the activation curves and droplet diameters of activated $\mathrm{CCN}$ in the CFSTGC. The instruments were calibrated this way numerous times throughout the study (Fig. 2); the resulting (absolute) uncertainty in effective supersaturation was $0.03 \%$ at $0.61 \%$ supersaturation, $0.05 \%$ at $1.02 \%$ for the CFSTGC, and, $0.02 \%$ at $0.6 \%$ supersaturation for the SD.

\subsection{Characterizing the water-soluble fraction of SOA}

In experiment $3, \beta$-caryophyllene SOA oxidized in the presence of $\mathrm{O}_{3}$ (Table 1) was collected on a Teflon filter and subsequently used to characterize the properties of its watersoluble organic carbon (WSOC) fraction. The WSOC in the filter samples was extracted with $20 \mathrm{ml}$ of ultra-pure water (18 Mohms) during a $1.5 \mathrm{~h}$ sonication process with heat (bath water temperature $\sim 60^{\circ} \mathrm{C}$; Asa-Awuku et al., 2007, 2008; Sullivan and Weber, 2006). The WSOC concentration was measured with a Total Organic Carbon (TOC)

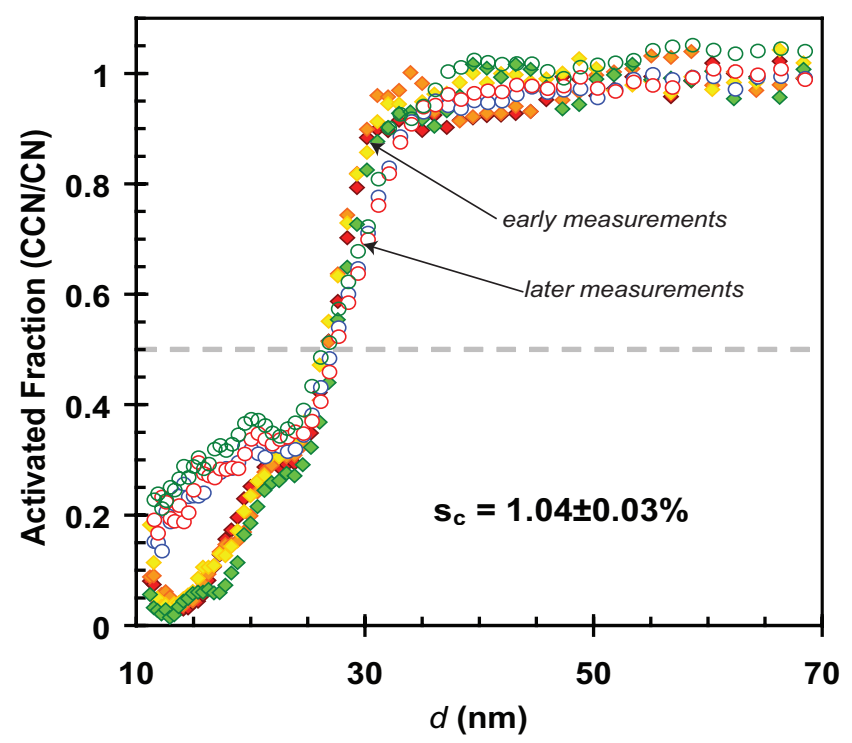

Fig. 2. Examples of activation fraction versus mobility diameter for $\left(\mathrm{NH}_{4}\right)_{2} \mathrm{SO}_{4}$ calibration aerosol. Measurements obtained with the CFSTGC.

Turbo Siever analyzer (Sullivan and Weber, 2006) and found to be $10.8 \mu \mathrm{g} \mathrm{C} \mathrm{mL}^{-1}$. The extracted sample is subsequently atomized, dried, size selected, and characterized for its $\mathrm{CCN}$ activity (following the procedure of Asa-Awuku et al., 2007) using SMCA between 0.2 and $1.4 \%$ supersaturation. This procedure is repeated for pure WSOC and mixtures with $\left(\mathrm{NH}_{4}\right)_{2} \mathrm{SO}_{4}$, the composition of which is verified with ion chromatography (IC) analysis. Köhler Theory Analysis (KTA), combined with the CCN activity measurements, are used to infer the molecular weight, surface tension (AsaAwuku et al., 2007; Padró et al., 2007; Moore et al., 2008), and droplet growth kinetic characteristics (Asa-Awuku et al., 2007).

The concentration of WSOC extracted from filter samples is often too low ( $\left.100 \mathrm{mg} C \mathrm{~L}^{-1}\right)$ to have a measurable impact on surface tension; $\sigma$ measurements relevant for $\mathrm{CCN}$ activation need to be obtained at much higher WSOC concentrations (>500 mg C L $\mathrm{L}^{-1}$ ) (Asa-Awuku et al., 2007). Although concentrating these solutions is possible, obtaining the required volume of organic sample is often impractical (Asa-Awuku et al., 2007). It is possible, however, to infer the surfactant characteristics of the SOA from the CCN activity of pure WSOC and mixtures with $\left(\mathrm{NH}_{4}\right)_{2} \mathrm{SO}_{4}$, following the procedure of Asa-Awuku et al. (2007) and Moore et al. (2008). 
Table 2. Formulae for the sensitivity of $M_{o} / \rho_{o}$ to the dependant parameters, when applied the WSOC fraction of the SOA.

\begin{tabular}{ll}
\hline Property $x$ & Sensitivity, $\Phi_{x}=\frac{\partial}{\partial x}\left(\frac{M_{o}}{\rho_{o}}\right)$ \\
\hline$\sigma$ & $\Phi_{\sigma}=\left(\frac{3 \times 256}{27}\left(\frac{M_{w}}{\rho_{w}}\right)^{2}\left(\frac{1}{R T}\right)^{3} \frac{\sigma^{2} \omega^{-2}}{v_{o}}\right)\left(\frac{M_{o}}{\rho_{o}}\right)^{2}$ \\
$\omega$ & $\Phi_{\omega}=\left(\frac{2 \times 256}{27}\left(\frac{M_{w}}{\rho_{w}}\right)^{2}\left(\frac{1}{R T}\right)^{3} \frac{\sigma^{3} \omega^{-3}}{v_{o}}\right)\left(\frac{M_{o}}{\rho_{o}}\right)^{2}$ \\
$v_{o}$ & $\Phi_{v_{o}}=\frac{256}{27}\left(\frac{M_{w}}{\rho_{w}}\right)^{2}\left(\frac{1}{R T}\right)^{3}\left(\frac{M_{o}}{\rho_{o}}\right)^{2} \sigma^{-3} \omega^{-2} v_{o}^{-2}$ \\
\hline
\end{tabular}

\section{Data analysis}

\subsection{Köhler theory analysis of WSOC}

Köhler Theory Analysis (KTA) (Asa-Awuku et al., 2008; Padró et al., 2007) is used to infer the average molar volume (molecular weight, $M_{o}$, over density, $\rho_{o}$ ) of the water-soluble organic fraction. KTA, when applied to organic aerosol of known composition, has been shown to yield organic molar volumes to within 20\% (Padró et al., 2007). KTA has also been applied to biomass burning aerosol (Asa-Awuku et al., 2008), WSOC from alkene ozonolysis (Asa-Awuku et al., 2007) and marine organic matter (Moore et al., 2008), where inferred $\sigma$ was in agreement with direct measurements using the pendant drop technique. KTA has also been used to infer the soluble fraction and the molecular weights of watersoluble components of monoterpene SOA (Engelhart et al., 2008).

KTA employs measurements of the activation diameter, $d$, for a range of critical supersaturation, $s_{c}$, to obtain a Fitted CCN Activity (FCA) factor, $\omega$, as $s_{c}=\omega d^{-3 / 2}$. If the organic particle is assumed to be composed of a soluble and insoluble fraction, FCA can be used to infer the average organic molar volume, $M_{o} / \rho_{o}$, as

$$
\frac{M_{o}}{\rho_{o}}=\frac{\varepsilon v_{o}}{\frac{256}{27}\left(\frac{M_{w}}{\rho_{w}}\right)^{2}\left(\frac{1}{R T}\right)^{3} \sigma^{3} \omega^{-2}}
$$

where $R$ is the universal gas constant, $T$ is the measurement temperature, $M_{w}$ and $\rho_{w}$ are the molecular weight and density of water, respectively, $\varepsilon$ is the soluble volume fraction, and $\sigma$ is the surface tension of the droplet at the point of activation (Sect. 3.2). For aerosol composed solely of WSOC, we assume that $\varepsilon=1$, and the organic effective van't Hoff factor, $v_{o}=1$.

$M_{o} / \rho_{o}$ is computed for each $s_{c}, d$ point and an average value is obtained. The average molecular weight, $M_{o}$, is then computed by assuming a density of $1500 \mathrm{~kg} \mathrm{~m}^{-3}$ (Kostenidou et al., 2007). For consistency, the standard deviation in $M_{o} / \rho_{o}$ is compared against the estimated molar volume uncertainty, $\Delta\left(\frac{M_{o}}{\rho_{o}}\right)=\sqrt{\sum_{x}\left(\Phi_{x} \Delta x\right)^{2}}$, where $\Delta x$ is the uncertainty of each of the measured parameters $x$, (i.e. any of $\sigma, \omega$, and $\nu$ ) and $\Phi_{x}$ is the sensitivity of molar volume to $x, \Phi_{x}=\frac{\partial}{\partial x}\left(\frac{M_{o}}{\rho_{o}}\right)$ (Table 2; Padró et al., 2007; Asa-Awuku et al., 2007, 2008).

\subsection{Inferring surface tension}

If $\mathrm{CCN}$ activity data is available for mixtures of WSOC and a salt (e.g. $\left.\left(\mathrm{NH}_{4}\right)_{2} \mathrm{SO}_{4}\right)$, KTA can be used to concurrently infer $M_{o} / \rho_{o}$ and $\sigma$ (as a function of WSOC concentration) using an iterative procedure (Moore et al., 2008). However, if enough salt is present in the sample, the contribution of organic solute is negligible; the effect of the organic on CCN activity amounts to its impact on surface tension, and can be inferred as (Asa-Awuku et al., 2007),

$\sigma=\sigma_{w}\left(\frac{s_{c}}{s_{c}^{*}}\right)^{2 / 3}$

where $s_{c}$ is the measured critical supersaturation, and $s_{c}^{*}$ is the predicted value (from Köhler theory), assuming $\sigma=\sigma_{w}$, the surface tension of pure water computed at the average CFSTGC column temperature (Asa-Awuku et al., 2007),

$s_{c}^{*}=\frac{4}{27}\left(\frac{4 M_{w} \sigma_{w}}{R T \rho_{w}}\right)^{1.5}\left(\frac{M_{w} d^{3}}{\rho_{w}}\left[\frac{\varepsilon_{i} v_{i} \rho_{i}}{M_{i}}+\frac{\varepsilon_{j} v_{j} \rho_{j}}{M_{j}}\right]\right)^{-0.5}$

where the subscript $i$ and $j$ denote the inorganic salt and organic properties, respectively. In this study, both the methods of Asa-Awuku et al. (2007) and Moore et al. (2008) are applied to infer $\sigma$ as a function of carbon concentration.

\subsection{Inferring the WSOC fraction in the SOA}

The SOA formed during the ozonolysis can be described as a mixture of a water-soluble and insoluble fractions. Assuming the extracted WSOC is similar to the soluble fraction of SOA, we can use the $M_{o} / \rho_{o}$ and $\sigma$ of the WSOC estimated by KTA (Sect. 3.1 and 3.2) to infer the $\varepsilon$ for the SOA. This is done by solving Eq. (1) for $\varepsilon$,

$\varepsilon=\frac{256}{27}\left(\frac{M_{w}}{\rho_{w} R T}\right)^{3}\left(\frac{M_{o}}{\rho_{o}}\right)\left(\frac{\rho_{w}}{M_{w}}\right) \frac{\sigma^{3} \omega^{-2}}{v_{o}}$

\subsection{Quantifying the droplet growth kinetics}

The extent to which droplets grow in each instrument depends on the supersaturation profile, residence time, droplet growth kinetic behavior, and to a lesser degree, dry particle size (Nenes et al., 2001). We quantitatively describe the growth of SOA by simulating the process of droplet formation within each $\mathrm{CCN}$ counter using comprehensive computational fluid dynamic models: the SD chamber model of Nenes et al. (2001), and, the DMT CFSTGC model of Lance et al. (2006). Each of these models numerically simulates the temporal and spatial distributions of velocity, pressure, temperature and water vapor concentration throughout 
the growth chamber of each instrument (the particle and gas phases are coupled through release of latent heat and condensational loss of water vapor); the fields are then used to drive the condensation growth of a population of aerosol as it flows through the instrument. The kinetic model includes aerosol with size-dependant composition; condensation growth of aerosol is computed based on a size-dependant mass transfer coefficient (Nenes et al., 2001) multiplied by the difference between gas-phase and equilibrium water vapor pressure. The latter is calculated with a comprehensive implementation of Köhler theory that accounts for multicomponent aerosol consisting of soluble, partially soluble and insoluble material. Organic surfactants can be present in any of these fractions.

The CCN models were initialized using the appropriate geometric dimensions and operating conditions of each CCN instrument (Sect. 2.2). A computational grid of 200 cells in the radial and 200 cells in the axial direction was used in each simulation; condensational growth and gravitational settling in the SD simulations commences after steady state is established for all gas-phase profiles. In CFSTGC simulations, the droplet diameter at the exit of the flow chamber is then compared against the measured size distribution, following the binning scheme used in the optical detection of the instrument (Lance et al., 2006). Particles with diameter larger than $2 \mu \mathrm{m}$ are counted as droplets in the SD simulations. Organics are allowed to affect the growth kinetics of $\mathrm{CCN}$ by modifying surface tension, equilibrium vapor pressure and the water uptake coefficient used to compute the water-vapor mass transfer coefficient (Nenes et al., 2001; Lance et al., 2006).

\section{Results and discussion}

\subsection{The diversity of observed CCN activity}

Figure 3 presents the CCN activity of $100 \mathrm{~nm}$ SOA particles (formed with and without $\mathrm{OH}$ in experiments 1 and 2), concurrently measured by the SD and CFSTGC at approximately the same $(0.6 \%)$ supersaturation (Table 1$)$. CCN activity is presented in terms of an activated fraction, the ratio of $\mathrm{CCN} / \mathrm{CN}$. The gradual increase in $\mathrm{CCN}$ activity suggests active chemical aging of the aerosol; this is in agreement with Donahue et al. (2005), although it is unclear if it is from oxidation in the gas or aerosol phase. Although both CCN instruments show an increase of activity with aging, the magnitudes and trends of the activated fractions are remarkably different. First, SOA formed in experiment 1 without $\mathrm{OH}$ appears more $\mathrm{CCN}$ active in the SD counter than SOA formed with $\mathrm{OH}$ oxidation (experiment 2), whereas the $\mathrm{CF}$ STGC measurements show the opposite. Secondly, SOA in the $\mathrm{SD}$ counter ages more rapidly (i.e., $\mathrm{CCN} / \mathrm{CN}$ has a larger slope) than in the CFSTGC; the SD aerosol ages at a rate of 0.10 and $0.07 \mathrm{CCN} / \mathrm{CN} \mathrm{h}^{-1}$ for SOA formed without and

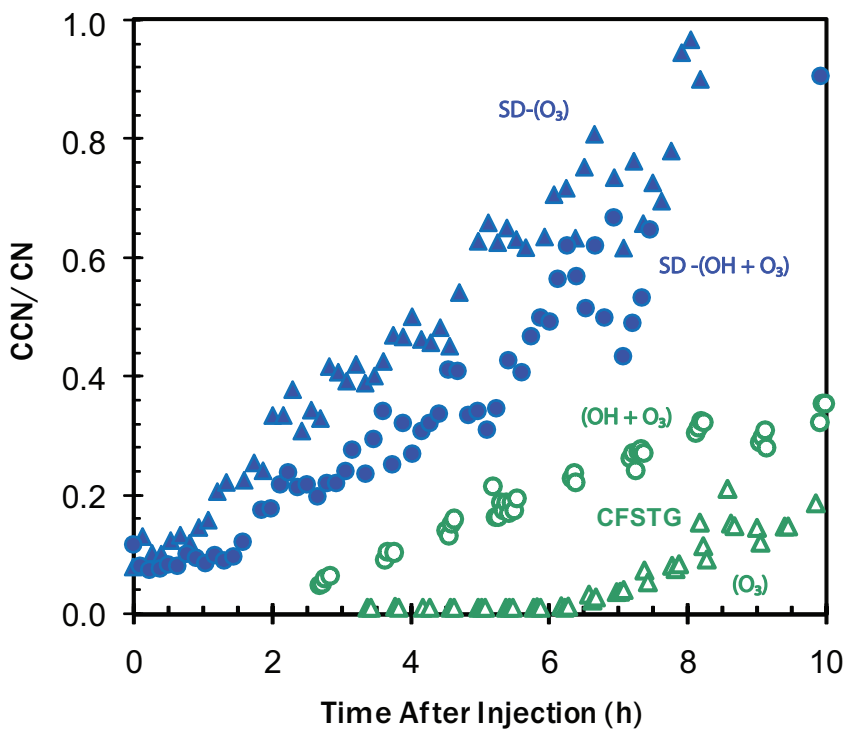

Fig. 3. $\mathrm{CCN}$ activity (at $\sim 0.6 \%$ supersaturation) of $100 \mathrm{~nm} \beta$ caryophyllene SOA formed in the presence of $\mathrm{OH}$ (circles) and without $\mathrm{OH}$ (triangles). Data from the CFSTGC and SD CCN counters are presented from experiments 1 and 2 .

in the presence of $\mathrm{OH}$, respectively. Aging in the CFSTGC counter commences at 0.02 and $0.04 \mathrm{CCN} / \mathrm{CN} \mathrm{h}^{-1}$ for SOA formed without and in the presence of $\mathrm{OH}$, respectively. Finally, $\mathrm{CCN}$ are immediately measured in the SD, while up to $6 \mathrm{~h}$ are required to register the first $\mathrm{CCN}$ counts in the $\mathrm{CF}$ STGC (Figs. 3 and 4). The discrepancy in measured CCN activity is most likely not an experimental artifact, as both instruments agree very well for calibration $\left(\mathrm{NH}_{4}\right)_{2} \mathrm{SO}_{4}$ and monoterpene SOA (Engelhart et al., 2008). We postulate that $\beta$-caryophyllene SOA (at least the hygroscopic component) partially evaporates in the CFSTGC, given that it is operated at $\sim 10^{\circ} \mathrm{C}$ above the chamber temperature. Conversely, vapors may condense onto the $\mathrm{CCN}$ in the $\mathrm{SD}$ given that particles are exposed to supersaturation at roughly $1^{\circ} \mathrm{C}$ below the chamber temperature (though significant composition changes due to this minor difference in temperature are unlikely). Changes in instrument operation conditions can thus affect the measured CCN properties of the aerosol. If true, this suggests that the hygroscopic fraction from the $\beta$ caryophyllene SOA formed during the reaction with $\mathrm{O}_{3}$ tends to be more volatile than the hygroscopic SOA formed during the reaction with $\mathrm{OH}$. The SD counter results in experiments 1 and 2 also suggest that the ozonolysis products are better $\mathrm{CCN}$ than the products of $\mathrm{OH}$ reaction.

Similar behavior is also seen at higher supersaturations (Fig. 4). Consistently with Fig. 3, the SOA ages significantly over time. SOA formed in the absence of $\mathrm{OH}$ requires a very long time $(\simeq 4 \mathrm{~h})$ before any $\mathrm{CCN}$ counts are registered by the CFSTGC; SOA formed in the presence of $\mathrm{OH}$ generates $\mathrm{CCN}$ almost immediately. 


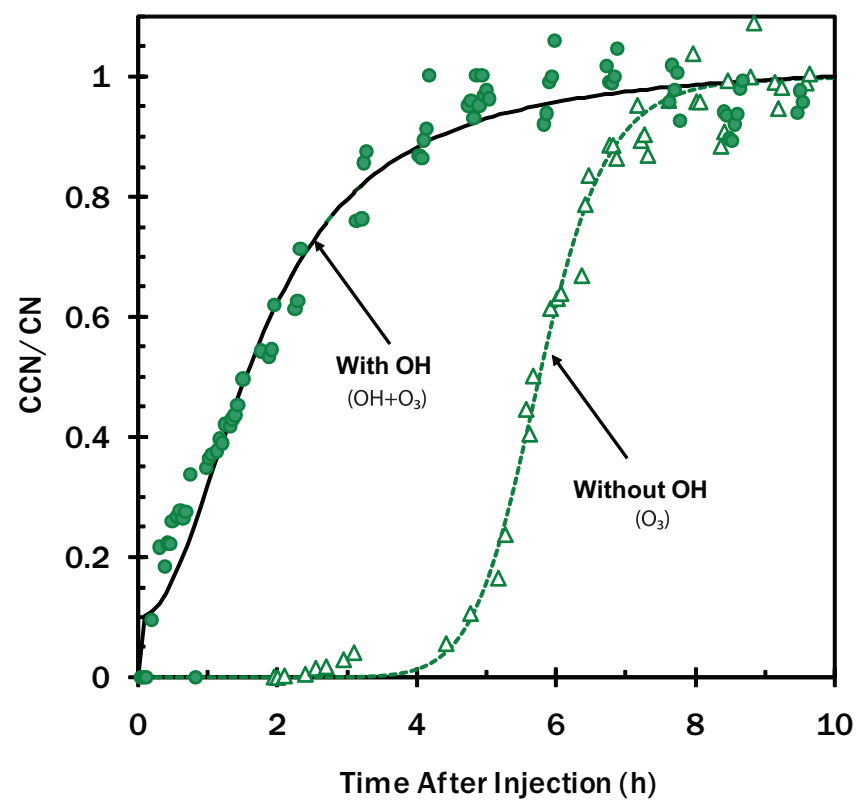

Fig. 4. CCN activity of $100 \mathrm{~nm} \beta$-caryophyllene SOA formed in the presence of $\mathrm{OH}$ (circles) and without $\mathrm{OH}$ (triangles). Measurements are obtained with the CFSTGC at $1.02 \%$ supersaturation from experiments 1 and 2 .

\subsubsection{Understanding the CCN activity}

To characterize the time-dependant CCN behavior, SMCA is applied to SOA formed in the presence and absence of $\mathrm{OH}$ (Fig. 5). In these measurements, $\mathrm{CCN}$ activity is quantified by the activation diameter, $d$, defined as the size of particles with $s_{c}$ equal to the instrument supersaturation; this is determined by the dry aerosol diameter for which $\mathrm{CCN} / \mathrm{CN}=0.5$. $d$ is determined for measurements with the SD in experiments 4 and 5 using the methods of Cruz and Pandis (1997) (Sect. 2.2).

In the absence of $\mathrm{OH}$, the SD counter initially measures $d \simeq 102 \mathrm{~nm}$ at $s=0.6 \%$ and decreases gradually with time at a rate of around $-1 \mathrm{~nm} \mathrm{~h}^{-1}$ (Fig. 5a). In the absence of $\mathrm{OH}$ and at $s=1.02 \%$, the CFSTGC cannot determine $d$ within the first five hours due to insufficient CCN counts $(<10 \mathrm{CCN}$ $\mathrm{cm}^{-3}$ ). Compared to the $\mathrm{SD}$, the slope of $d$ with time in the CFSTGC is three times larger, suggesting that the volatility of the hygroscopic material in experiments 1 and 2 may change with time. Beyond the sixth hour, the $\mathrm{CCN}$ activity of CFSTGC measurements (i.e. $d$ ) for both types of SOA (with and without $\mathrm{OH}$ oxidation in experiments 1 and 2) and supersaturations considered agree to within 5\%, suggesting that the oxidized products of both SOA types become similar (Fig. 4).

To verify that aerosol volatility accounts for the differences seen in the CCN activity between instruments, we pass the most volatile SOA (i.e. formed with $\mathrm{OH}$ absent)
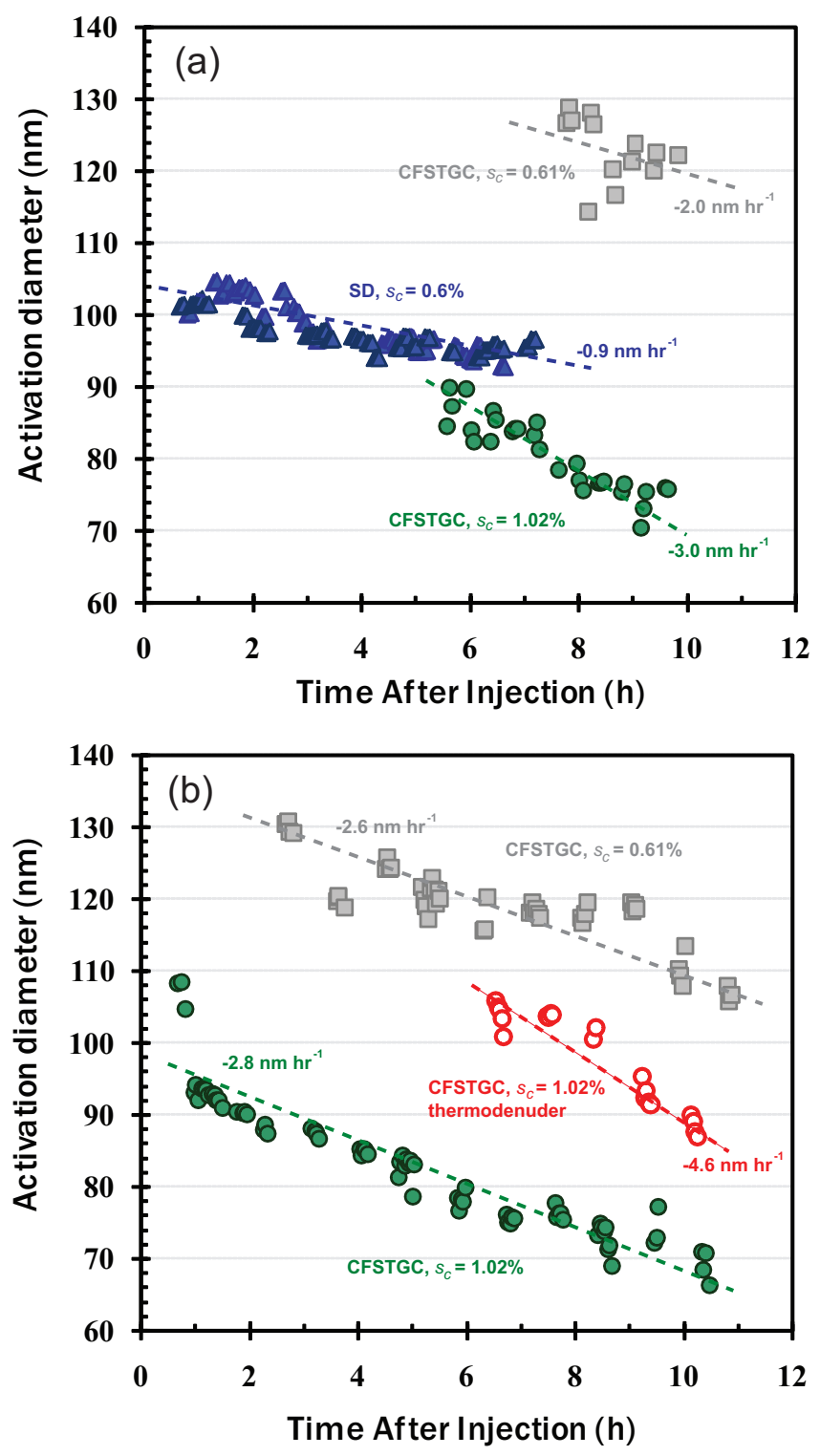

Fig. 5. Activation diameter as a function of time. (a) SOA formed without $\mathrm{OH}$ in experiments 1 (CFSTGC at $s_{c}=0.61 \%$ : grey squares; $s_{C}=1.02 \%$ : green circles), 4 and 5 (SD at $s_{C}=0.6 \%$ : blue triangles). (b) SOA formed with $\mathrm{OH}$ in experiment 2. CFSTGC measurements at $s_{C}=0.61 \%$ (grey squares), and $s_{C}=1.02 \%$ (green circles) are shown. Open red circles correspond to aerosol passed through the thermodenuder prior to exposure to $1.02 \%$ supersaturation in the CFSTGC.

through a thermodenuder before introduction into the CFSTGC. SMCA is applied to measurements at $0.61 \%$ and $1.02 \%$ supersaturation; however, the lack of $\mathrm{CCN}$ counts at the lower supersaturation prohibits the determination of $d$ for the whole experiment. For similar reasons, the $\mathrm{CCN}$ activity of thermodenuded SOA at $1.02 \%$ can not be determined during the first six hours of the experiment (Fig. 5b). When 
$\mathrm{CCN}$ counts are possible, $d$ significantly increases $(\sim 25 \%)$ when the SOA is passed through the thermodenuder. This suggests that the non-volatile aerosol exiting the thermodenuder is less CCN-active than the semi-volatile material, and that the latter is primarily responsible for the observed $\mathrm{CCN}$ activity of freshly formed SOA.

Since the CFSTGC is operated at conditions similar to the thermodenuder, some of the soluble material will evaporate in the $\mathrm{CCN}$ instrument and exhibit reduced $\mathrm{CCN}$ activity. In the SD instrument however, particles are exposed to supersaturation at one degree below chamber temperature (because the temperature difference between plates is $\sim 2^{\circ} \mathrm{C}$, and $s_{\max }$ in the instrument is located halfway between plates). It is therefore expected that the SD measurements reflect the $\mathrm{CCN}$ activity of the particles in the smog chamber, and any additional condensation of SOA in the SD chamber (because of the 1 degree difference) will have a minor impact on composition and $\mathrm{CCN}$ activity.

A perceived decrease in $\mathrm{CCN}$ activity could also be a result of kinetic limitations, when the droplets are not allowed enough time to grow to detectable sizes (Lance et al., 2006). In the CFSTGC, CCN are allowed to grow for 10-30 s; if the SOA are kinetically limited, activation in the SD should require about the same time. This is however not true, as droplets in the SD form in less than $5 \mathrm{~s}$ (Sect. 4.4). Hence, the reduced CCN activity is not from kinetic limitations and reflects changes in the aerosol hygroscopicity.

The SOA, when activated close to the chamber temperature (i.e. in the SD) seems to contain more hygroscopic material, compared to when it is activated in the CFSTGC (Fig. 5). Minor differences in CCN activity are also seen between $\mathrm{SOA}$ formed from $\mathrm{O}_{3}$ and $\mathrm{O}_{3}+\mathrm{OH}$ oxidation, reflected in the SD measurements as a small difference in $\mathrm{CCN}$ activity between the two SOA types (Fig. 3). After sufficient aging has occurred, the volatility of organic components may decrease enough for $\mathrm{CCN}$ activity measurements from the SD and CFSTGC to converge; this was not seen however in any of the experiments conducted in this study.

\subsection{Characterization of the hygroscopic fraction}

Figure 6 displays the $s_{c}$ vs. $d$ for $\beta$-caryophyllene SOA and the WSOC extracted from it. For comparison, we also present data for WSOC extracted from monoterpene SOA (Engelhart et al., 2008) and $\left(\mathrm{NH}_{4}\right)_{2} \mathrm{SO}_{4}$. The results show that aerosol generated from $\beta$-caryophyllene WSOC are more $\mathrm{CCN}$-active than the original SOA, but less $\mathrm{CCN}$ active than $\left(\mathrm{NH}_{4}\right)_{2} \mathrm{SO}_{4}$. Surprisingly, the CCN activity of WSOC from oxidation of monoterpenes and $\beta$-caryophyllene is remarkably similar. Gas Chromatography- Mass Spectrometry (GC-MS) analysis of the $\beta$-caryophyllene sample exclude the presence of monoterpenes; hence similarity of WSOC properties is most likely an inherent property of the WSOC. Despite this, the CCN activity of monoterpene and $\beta$-caryophyllene SOA is substantially different (the latter
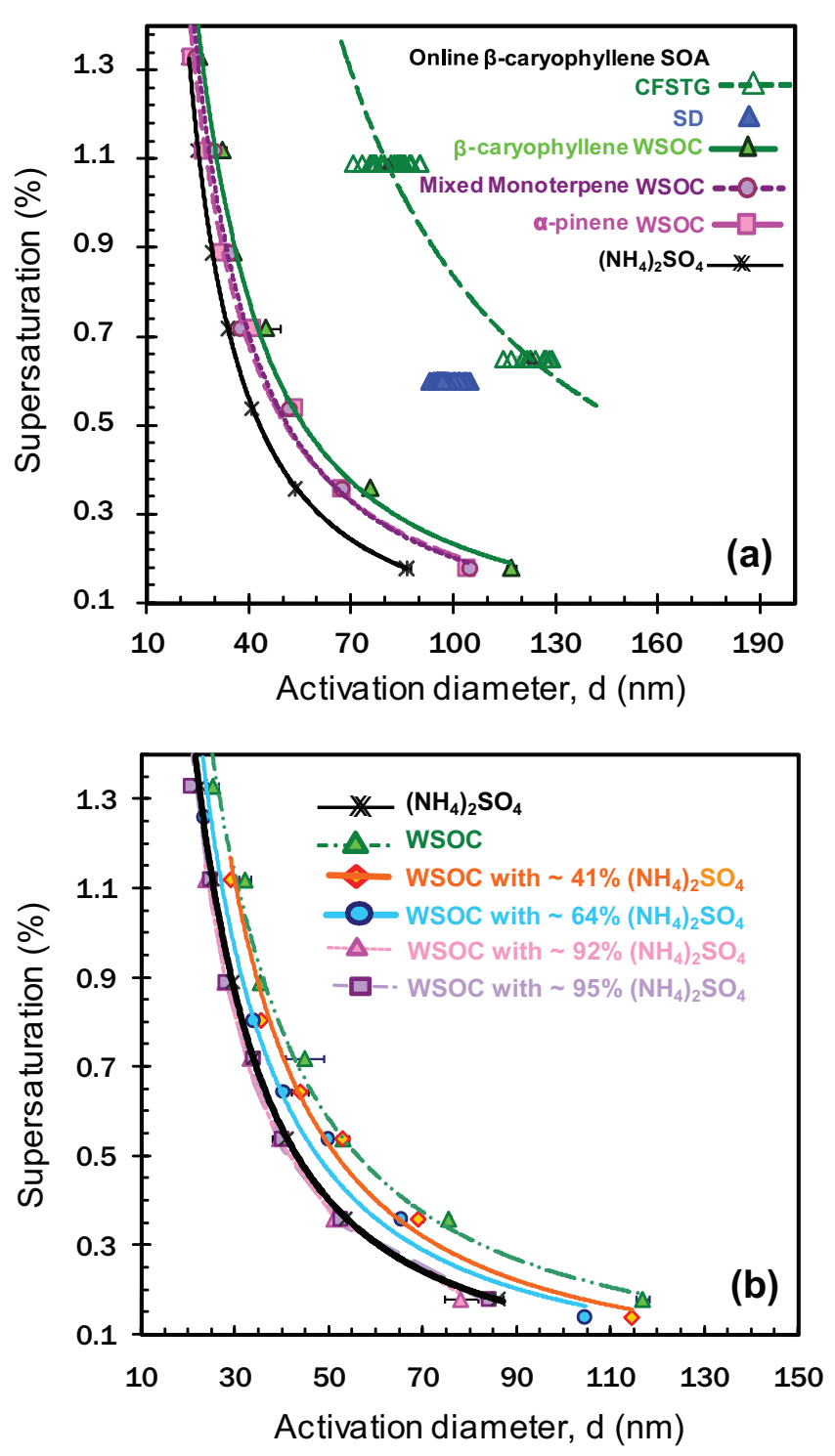

Fig. 6. CCN Activity of WSOC from $\beta$-caryophyllene SOA collected in experiment 3. (a) SOA and $\left(\mathrm{NH}_{4}\right)_{2} \mathrm{SO}_{4}$ data are presented for comparison. WSOC from mixed monoterpene and $\alpha$-pinene hydrocarbon precursors (Engelhart et al., 2008) are also shown. (b) WSOC from $\beta$-caryophyllene SOA, mixed with $\left(\mathrm{NH}_{4}\right)_{2} \mathrm{SO}_{4}$.

being less hygroscopic, Huff-Hartz et al., 2005; Engelhart et al., 2008, Fig. 6) suggesting that the amount of WSOC in sesquiterpene SOA is much less than in monoterpene SOA.

The molecular weight of the WSOC fraction is summarized in Table 3, along with the relevant KTA parameters. The average molecular weight of the WSOC was found to be $156 \pm 44 \mathrm{~g} \mathrm{~mol}^{-1}$ (Table 3 ). This level of CCN activity is similar to low molecular weight organic species $\left(<200 \mathrm{~g} \mathrm{~mol}^{-1}\right)$ that are moderately surface active (Henning et al., 2005; Padró et al., 2007; Raymond and Pandis, 2002). The molar 
Table 3. Köhler Theory Analysis parameters, molar volume results and uncertainty analysis for the water-soluble fraction of $\beta$-caryophyllene SOA.

\begin{tabular}{lllll}
\hline $\begin{array}{l}\text { Property } x \\
\text { (units) }\end{array}$ & $\begin{array}{l}\text { Average } \\
\text { Value of } x\end{array}$ & $\begin{array}{l}\text { Uncertainty } \\
\Delta x\end{array}$ & $\begin{array}{l}\text { Sensitivity, } \Phi_{x} \\
\left(\mathrm{~m}^{3} \mathrm{~mol}^{-1} x^{-1}\right)\end{array}$ & $\begin{array}{l}M_{o} / \rho_{o} \text { uncertainty } \\
\text { contribution }(\%)\end{array}$ \\
\hline FCA, $\omega\left(\mathrm{m}^{1.5}\right)$ & $6.86 \times 10^{-14}$ & $1.01 \times 10^{-15}$ & $3.21 \times 10^{9}$ & 3.4 \\
$\sigma\left(\mathrm{N} \mathrm{m}^{-1}\right)$ & $6.56 \times 10^{-2}$ & $1.32 \times 10^{-3}$ & $4.62 \times 10^{-3}$ & 7.0 \\
$v_{o}$ & 1 & $0.20^{\mathrm{a}}$ & $1.02 \times 10^{-4}$ & 23.4 \\
$M_{o} / \rho_{o}\left(\mathrm{~m}^{3} \mathrm{~mol}^{-1}\right)$ & $1.02 \times 10^{-4}$ & $24.8 \%$ & - & - \\
$M_{o}\left(\mathrm{~g} \mathrm{~mol}^{-1}\right)^{\mathrm{b}}$ & 156 & 44 & - & - \\
\hline
\end{tabular}

a based on up to $20 \%$ disassociation observed for HULIS (Dinar et al., 2006); ${ }^{\mathrm{b}} \rho_{s}=1500 \mathrm{~kg} \mathrm{~m}^{-3}$ (Kostenidou et al., 2007)

volume uncertainty is estimated to be $\sim 25 \%$ (Table 3 ) and is consistent with the observed variability in the inferred $M_{o} / \rho_{o}$ from previous KTA studies (e.g. Padró et al., 2007).

Low molecular weight species consistent with the KTA estimates have been identified in $\beta$-caryophyllene SOA, and could result from fragmentation reactions taking place during oxidation. Jaoui et al. (2003) identify 3,3-dimethyl-2-(3-oxobutyl)-cyclobutane-methanal and 3,3dimethyl-2-ethanal-cyclobutane, of molecular weight 192 and $154 \mathrm{~g} \mathrm{~mol}^{-1}$, respectively in the aerosol phase. Lee et al. (2006) using proton transfer reaction mass spectrometry (PTR-MS) measured several unknown compounds of mass charge ratio $(m / z)<250$. In particular, Lee et al. (2006) identified a compound with $m / z=159$ in the ambient and laboratory experiments of $\beta$-caryophyllene.

Addition of $\left(\mathrm{NH}_{4}\right)_{2} \mathrm{SO}_{4}$ to the WSOC mixture could produce better $\mathrm{CCN}$ than using pure $\left(\mathrm{NH}_{4}\right)_{2} \mathrm{SO}_{4}$ alone, if the organics depress surface tension. This is indeed the case, and shown in Fig. 6b; the activation curve of the aerosol composed of $92 \%$ sulfate should lie to the right of the pure $\left(\mathrm{NH}_{4}\right)_{2} \mathrm{SO}_{4}$. Instead, the organics (present in $\sim 10 \%$ ) depress surface tension (by $\sim 5 \%$ ) so that the mixture behaves like pure $\left(\mathrm{NH}_{4}\right)_{2} \mathrm{SO}_{4}$. Similar $\mathrm{CCN}$ enhancement from surface tension depression is also seen in monoterpene and marine WSOC (Engelhart et al., 2008; Moore et al., 2008), suggesting that this level of surface tension depression, with the exception of HULIS (Asa-Awuku et al., 2008), may be a robust characteristic of CCN containing water-soluble organics. Using the methods of Asa-Awuku et al. (2007) and Moore et al. (2008), the organics in the salted WSOC samples are inferred to depress $\sigma$ to $65.6 \pm 2.1 \mathrm{~m} \mathrm{~N} \mathrm{~m}^{-1}$.

\subsection{Estimating SOA soluble fraction}

Once the surface tension and average molar volume of the WSOC is determined, its volume fraction, $\varepsilon$, in the SOA can be inferred by applying Eq. (4) to the online CCN activation data. The result of this calculation is shown in Fig. 7a, where $\varepsilon$ is plotted against time for all the experimental data of Fig. 5. CCN activity is only observed when sufficient amounts $(\varepsilon>0.03)$ of soluble non-volatile material exist in the aerosol phase (Figs. 5 and 7). Figure 7a suggests that $\varepsilon$ is minimum for aerosol processed in the thermodenuder, since that is when $d$ is maximum (Fig. 5), and is consistent with the hypothesis of WSOC volatility.

Analyzing the temporal trend of inferred $\varepsilon$ (Fig. 7a) yields some very interesting aspects of the SOA aging process. Early on in the experiment $(0-5 \mathrm{~h})$, the $\varepsilon$ inferred from the CFSTGC $0.61 \%$ and $1.02 \%$ datasets is almost identical; this is consistent with the SOA being initially of uniform composition (and also confirms that the method to infer $\varepsilon$ gives consistent results across a wide range of operation conditions and experiments). Later on in the experiment (5-11 h), $\varepsilon$ between the two supersaturations diverge; the $1.02 \%$ dataset tends to infer a larger $\varepsilon$ than for the $0.61 \%$. This is consistent with size-dependant processing of the aerosol in the chamber; smaller particles (i.e. those with $s_{c}=1.02 \%$ ), because of differences in their surface-to-volume ratio, would tend to age more quickly than larger particles (i.e., those with $s_{c}=0.61 \%$ ). It is unclear however if this aging is from the condensation of gas-phase species, or chemical aging of material within the aerosol volume.

Figure $7 \mathrm{~b}$ presents the sensitivity of $\varepsilon$ to the value of $M_{o} / \rho_{o}$ and $\sigma$ used in Eq. (4); despite the large variations considered, $\varepsilon$ does not change by more than a factor of 1.5 and does not exceed $30 \%$. This finding is consistent with the hypothesis that the soluble (hygroscopic) material is present in small amounts in the aerosol; because of this, volatilization of small amounts of the soluble fraction will strongly impact CCN activity.

\subsection{Composition and droplet growth kinetics}

Figure 8 shows that more than six hours of aging are required before the SOA with $s_{c}=1.02 \%$ can grow to droplet sizes similar to those of $\left(\mathrm{NH}_{4}\right)_{2} \mathrm{SO}_{4}$; even more time is required for particles with $s_{c}=0.61 \%$. The range of observed growth kinetics is much larger than shifts in the particle equilibrium vapor pressure can account for, and are attributed to changes in the water vapor mass transfer coefficient. Combining the 

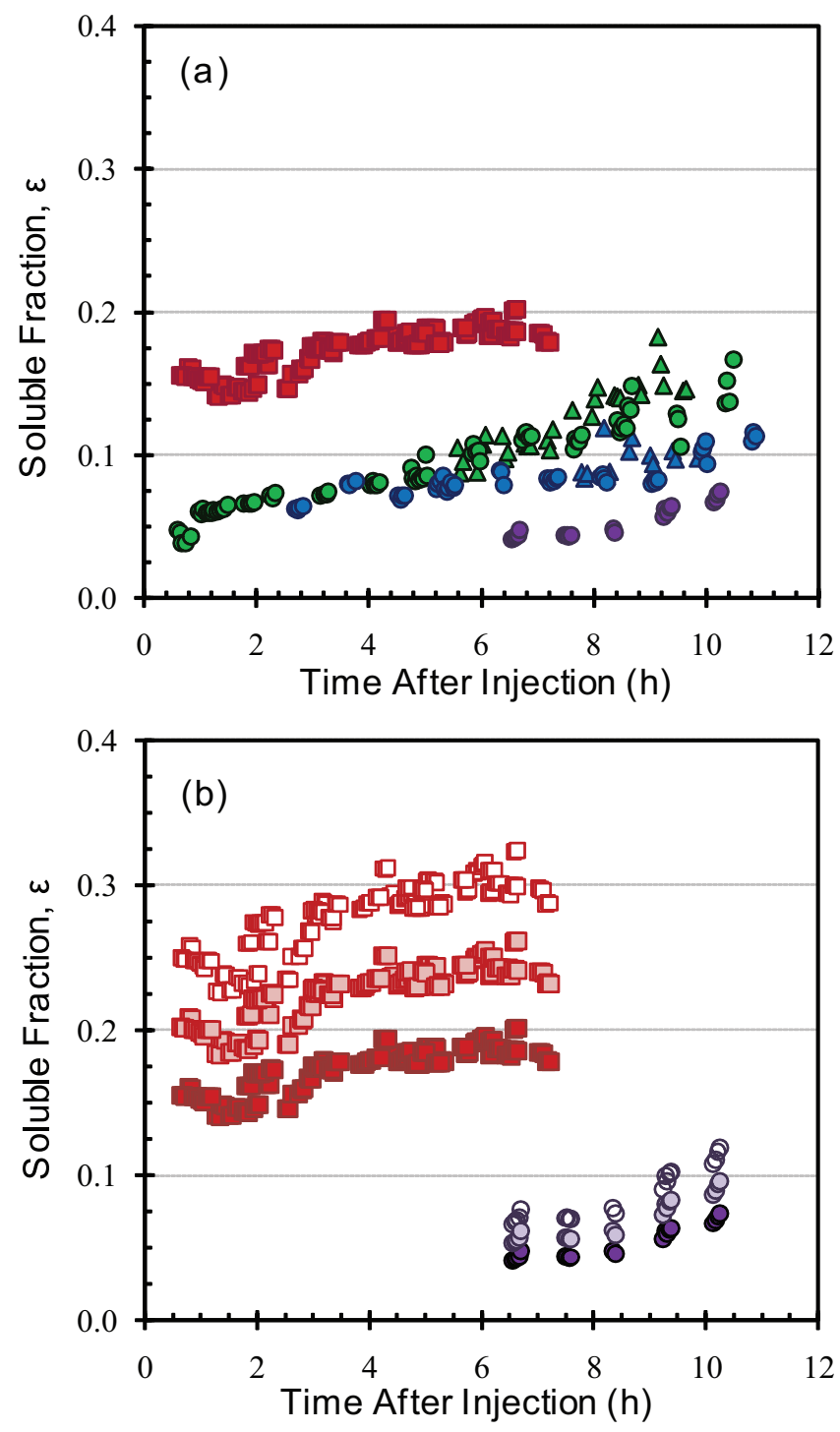

Fig. 7. Inferred soluble fraction as a function of aging for experiments 1,2, 4 and 5. Square symbols represent SD measurements; circles and triangles represent CFTGC measurements for SOA formed in the presence and absence of $\mathrm{OH}$, respectively. (a) $\varepsilon$ inferred assuming $\sigma=66 \mathrm{~m} \mathrm{~N} \mathrm{~m}^{-1}$ and $M_{O}=156 \mathrm{~g} \mathrm{~mol}^{-1}$ for SD measurements at $0.6 \%$ (red squares), CFSTGC measurements at $1.02 \%$ (green symbols), $0.61 \%$ (blue symbols), and, for aerosol passed through the thermodenuder and exposed to $1.02 \%$ supersaturation (purple symbols). (b) Sensitivity of $\varepsilon$ to $\sigma$ and $M_{O}$ for data obtained with the SD and (squares) and CFSTGC (circles): $\sigma=66 \mathrm{~m}$ $\mathrm{N} \mathrm{m}^{-1}, M_{o}=156 \mathrm{~g} \mathrm{~mol}^{-1}$ (darkest closed symbols), $\sigma=72 \mathrm{~m} \mathrm{~N}$ $\mathrm{m}^{-1}, M_{O}=156 \mathrm{~g} \mathrm{~mol}^{-1}$ (lightly shaded symbols), and, $\sigma=66 \mathrm{~m} \mathrm{~N}$ $\mathrm{m}^{-1}, M_{O}=250 \mathrm{~g} \mathrm{~mol}^{-1}$ (open symbols).

data in Figs. 7 and 8 indicates that the SOA droplet growth kinetics accelerate as $\varepsilon$ increases; this suggests that $i$ ) the insoluble material may somehow form surface films that can delay growth, and, ii) the chemical aging of the aerosol (ex-

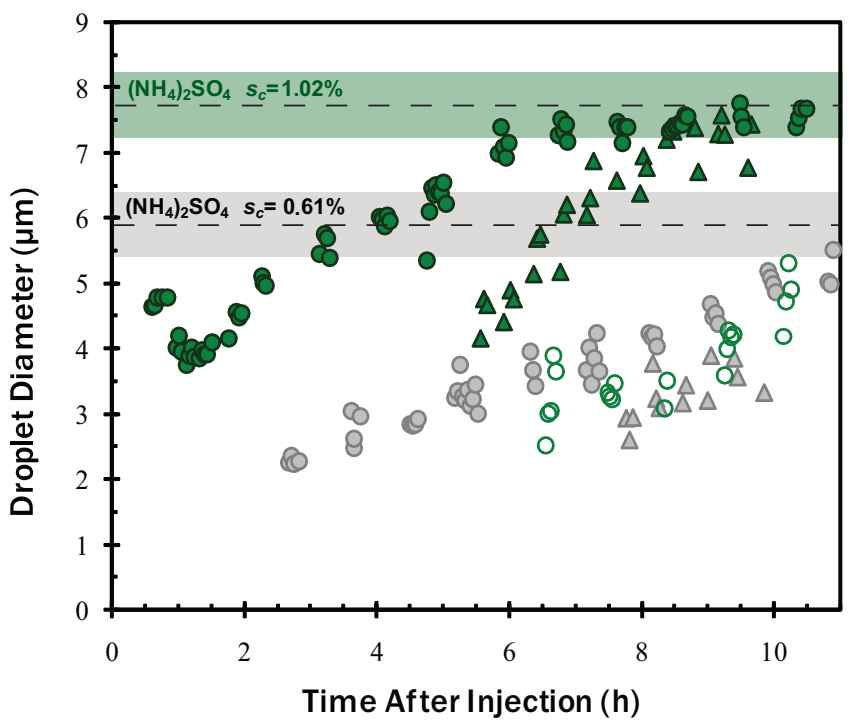

Fig. 8. Droplet diameters of activated SOA particles with $s_{C}$ equal to the instrument supersaturation, for experiments 1 (circles) and 2 (triangles). Results are shown for particles with $s_{c}=1.02 \%$ (closed and open) and $0.61 \%$ (grey) supersaturation. Aerosol passed through the thermodenuder is shown with open circles. The shaded green and grey bands represent the average droplet size of calibration $\left(\mathrm{NH}_{4}\right)_{2} \mathrm{SO}_{4}$ with critical supersaturation of $1.02 \%$ $(7.7 \pm 0.25 \mu \mathrm{m})$ and $0.61 \%(5.9 \pm 0.25 \mu \mathrm{m})$, respectively.

pressed as an increase in $\varepsilon$ ) eventually diminishes the extent of this delay.

Figure 9 presents droplet sizes of WSOC (pure and mixed with $\left.\left(\mathrm{NH}_{4}\right)_{2} \mathrm{SO}_{4}\right)$ as a function of $s_{c}$. For comparison, droplet sizes for pure $\left(\mathrm{NH}_{4}\right)_{2} \mathrm{SO}_{4}$ and SOA CCN are presented. The WSOC (pure and salted) behave much like $\left(\mathrm{NH}_{4}\right)_{2} \mathrm{SO}_{4}$, as the wet diameters for all samples are within one size bin $(0.5 \mu \mathrm{m})$ of the OPC sizing. This, combined with the marked delay in growth of SOA CCN (Figs. 8 and 9) strongly suggests that the source of kinetic limitations in the latter arises from the "insoluble" component of the SOA.

To compare the observed droplet growth kinetics in both $\mathrm{CCN}$ counters, we derive the $\alpha$ from the simulations of CCN activation in each instrument. Figure 10 shows the simulated normalized droplet concentration in the view volume of the $\mathrm{SD}$ (used for determining the CCN concentration), as a function of time and $\alpha$. The simulations suggest that $\alpha$ strongly influences the timing, but not the value, of peak droplet concentration; we therefore use the timing where the peak concentration is obtained to constrain $\alpha$ in the SD CCN measurements. The droplet formation timescale in the view volume was measured $4 \mathrm{~h}(3.70 \pm 0.60 \mathrm{~s})$ and $8 \mathrm{~h}(3.32 \pm 0.50 \mathrm{~s})$ into experiment 4, and are shown as dashed lines in Fig. 10; simulations suggest that the SOA water vapor uptake coefficient is low early on $(\alpha \sim 0.03)$ and increases to values consistent with $\left(\mathrm{NH}_{4}\right)_{2} \mathrm{SO}_{4}(2.23 \pm 0.19 \mathrm{~s})$ and hydrophilic 


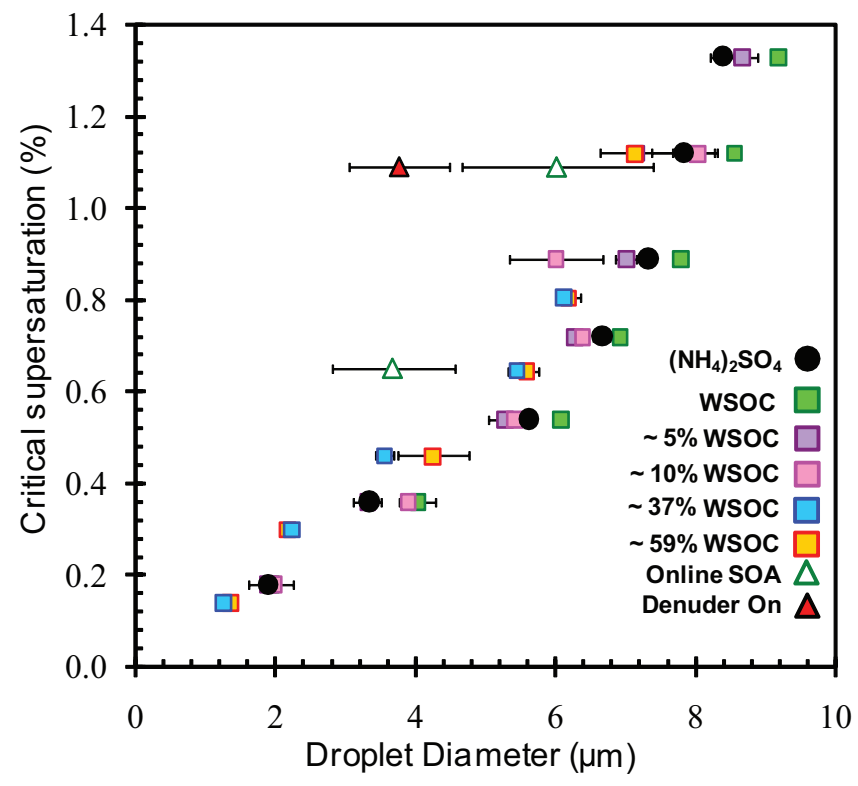

Fig. 9. Droplet sizes of WSOC CCN with $s_{c}$ equal to the instrument supersaturation (square symbols). Data is obtained from experiments 1, 2, and 3. Corresponding droplet sizes for $\left(\mathrm{NH}_{4}\right)_{2} \mathrm{SO}_{4}$ (black circles) and SOA CCN (triangles) are also shown.

(monoterpene) SOA. Although the variability in activation timescale is large, these shifts are statistically significant; values of $\alpha$ below 0.03 are highly unlikely, since the timing difference in the peak concentration becomes very large (Fig. 10).

Figure 11a shows the simulated droplet size at the exit of the CFSTGC column as a function of $\alpha$ for CCN with $s_{c}=1.02 \%$ (blue) and $0.61 \%$ (magenta). The size of activated calibration $\left(\mathrm{NH}_{4}\right)_{2} \mathrm{SO}_{4}$ with corresponding critical supersaturations is also shown; simulations suggest that the $\alpha$ for $\left(\mathrm{NH}_{4}\right)_{2} \mathrm{SO}_{4}$ particles ranges between 0.04 and 0.06 , which is consistent with expectations and the SD simulations. The agreement in inferred $\alpha$ between instruments confirms that the CFSTGC and SD models are a consistent representation of the growth kinetics in each instrument.

The simulations of Fig. 11a can be combined with the droplet size data of Fig. 8 to infer the water vapor uptake coefficient for the activated SOA in the CFSTGC, and is shown in Fig. 11b. Compared to the SD, growth kinetics in the CFSTGC are substantially slower, with the following characteristics: $i$ ) aerosol thermally treated in the thermodenuder exhibits the slowest behavior, with 4 times lower $\alpha$ than $\left.\left(\mathrm{NH}_{4}\right)_{2} \mathrm{SO}_{4}, i i\right)$ aerosol that is not pretreated in the thermodenuder exhibits slow growth kinetics early on in the experiment. Aging gradually accelerates growth, until it reaches the levels of ammonium sulfate (after $10 \mathrm{~h}$ of aging), and, iii) the growth at $s_{c}=0.61 \%$ is slower than particles with $s_{c}=1.02 \%$ particles and takes longer to reach "sulfate rates".

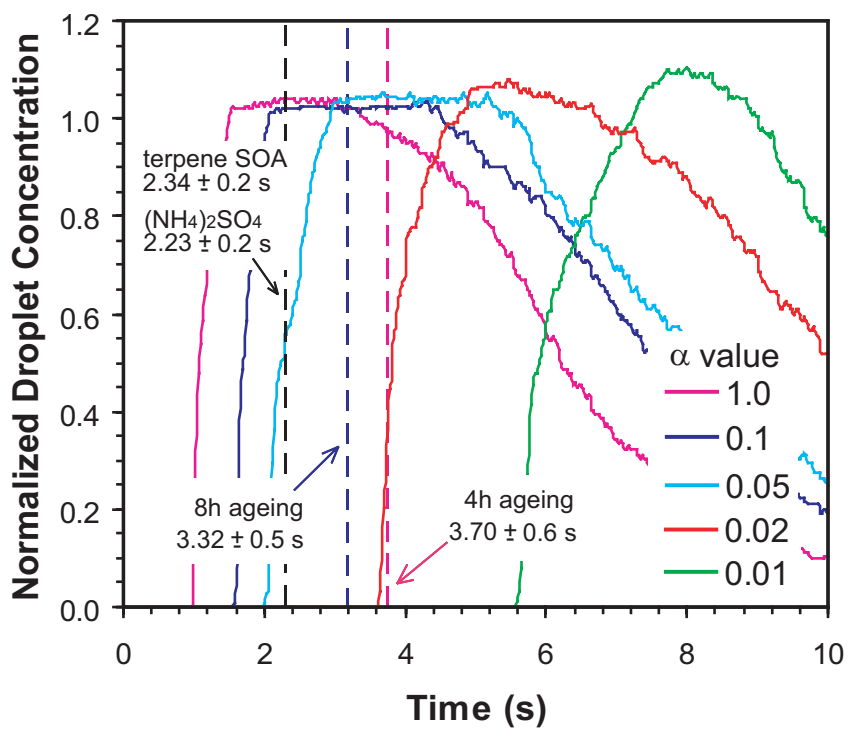

Fig. 10. Simulated droplet concentration within the viewvolume of the SD CCN Counter as a function of time and water vapor uptake coefficient. Peak supersaturation in the counter is $0.6 \%$, and initially is filled with monodisperse $(d=100 \mathrm{~nm}) \beta$-caryophyllene SOA composed of $10 \%$ WSOC (with the composition shown in Table 3 ).

The diverse range of uptake coefficients inferred for CCN in both instruments may at first seem counterintuitive, but is consistent with thermal processing of the SOA in the CFSTGC and thermodenuder. Modification of CCN can happen in many ways; for example, evaporation of hygroscopic volatile compounds, preferentially from the surface layers of the aerosol, and, redistribution of insoluble "waxy" material to the $\mathrm{CCN}$ surface, especially if the viscosity changes substantially in the $25-35^{\circ} \mathrm{C}$ range (i.e. it partially melts). In both cases, a "barrier" of insoluble and hydrophobic material could form between the hygroscopic fraction of the SOA, which would then decrease the growth rates of the activated $\mathrm{CCN}$. The available data seems to support the thermal modification hypothesis because $i$ ) $\alpha$ is strongly anticorrelated with the residence time at elevated temperatures, since $\mathrm{CCN}$ processed in the thermodenuder exhibits the slowest growth, followed by the CFSTGC data (with non-denuded aerosol) and the $\mathrm{SD}$, ii) $\mathrm{CCN}$ with $s_{c}=1.02 \%$ grow more quickly in the CFSTGC than those with $s_{c}=0.61 \%$, because the WSOC fraction in the former is higher, and, iii) given that particles with $s_{c}=1.02 \%$ have a smaller dry diameter than those with $s_{c}=0.61 \%$, the amount of insoluble material (hence the kinetic barrier) is much less; this explains why the aerosol establishes "rapid growth" kinetics towards the end of the experiment.

Other mechanisms can limit the growth rate of $\mathrm{CCN}$, but may not be active in $\beta$-caryophyllene SOA. For example, diffusion-controlled dissolution of the soluble material in the 

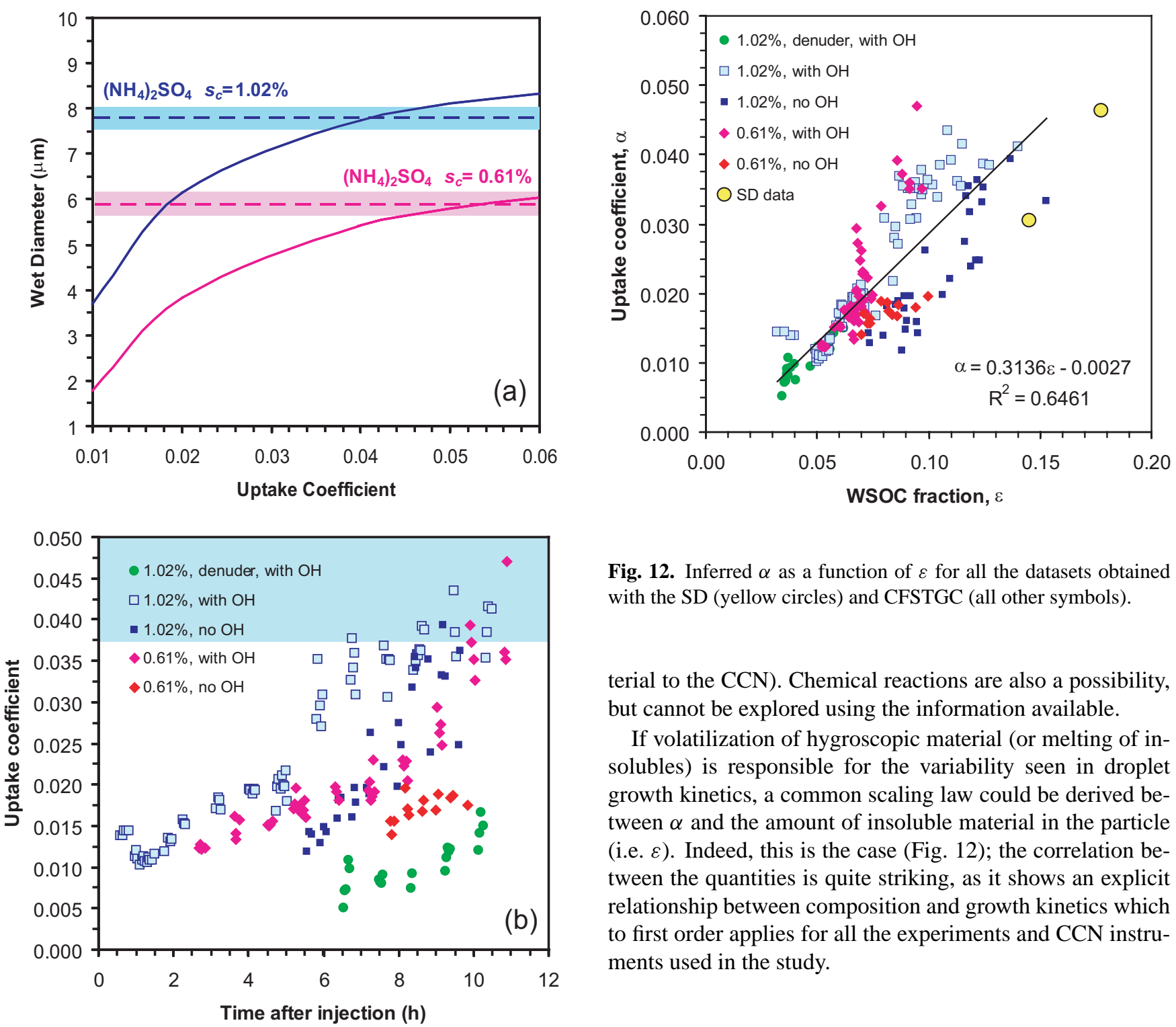

Fig. 12. Inferred $\alpha$ as a function of $\varepsilon$ for all the datasets obtained with the SD (yellow circles) and CFSTGC (all other symbols).

terial to the $\mathrm{CCN}$ ). Chemical reactions are also a possibility, but cannot be explored using the information available.

If volatilization of hygroscopic material (or melting of insolubles) is responsible for the variability seen in droplet growth kinetics, a common scaling law could be derived between $\alpha$ and the amount of insoluble material in the particle (i.e. $\varepsilon$ ). Indeed, this is the case (Fig. 12); the correlation between the quantities is quite striking, as it shows an explicit relationship between composition and growth kinetics which to first order applies for all the experiments and $\mathrm{CCN}$ instruments used in the study.

\section{Implications - conclusions}

Fig. 11. CFSTGC growth kinetics simulations for data collected during experiments 1 and 2. (a) Simulated droplet wet diameter at the exit of the CFSTGC as a function of $\alpha$ for CCN with $s_{c}=1.02 \%$ (blue) and $0.61 \%$ (magenta). The size of activated calibration $\left(\mathrm{NH}_{4}\right)_{2} \mathrm{SO}_{4}$ is also shown for comparison. (b) Inferred water vapor uptake coefficient for the growth kinetic data of Fig. 9. For comparison, the range of inferred $\alpha$ for $\left(\mathrm{NH}_{4}\right)_{2} \mathrm{SO}_{4}$ is shown in the blue shaded area.

CCN (Asa-Awuku and Nenes, 2007) is unlikely to be important, given that solute diffusivity (hence growth kinetics) should be faster at higher temperatures, contrary to what is seen in our experiments. Condensation/dissolution of material from the gas phase is also possible, but also unlikely, as the thermodenuded aerosol should then exhibit faster growth kinetics (because of higher mass transfer rates of soluble ma-

A combination of modeling with measurements of $\mathrm{CCN}$ activity, droplet growth kinetics and volatility provides a unique insight on the droplet formation characteristics of $\beta$ caryophyllene SOA. We find that the particles contain small amounts of hygroscopic material; hence, even if sesquiterpenes have higher aerosol yields than monoterpenes, they are less $\mathrm{CCN}$-active. From our KTA estimates, the WSOC constitute $5-10 \%$ of the SOA mass, moderately depresss surface tension and is composed (on average) of low molecular weight compounds $\left(<250 \mathrm{~g} \mathrm{~mol}^{-1}\right)$. Remarkably, these properties are similar to water-soluble organic carbon extracted from monoterpene oxidation (although the soluble volume fraction is much higher, between $70 \%$ and $100 \%$, Engelhart et al., 2008). This suggests that WSOC in biogenic SOA may have similar CCN properties (solubility, molecular weight and surfactant characteristics), and that differences in 
the $\mathrm{CCN}$ activity of SOA from different parent hydrocarbons may be primarily arise from the WSOC mass fraction; if true, this can constitute the basis for a simple and mechanisticallybased approach to represent the $\mathrm{CCN}$ activity of SOA as a function of atmospheric age (as one needs to only simulate the WSOC fraction of the SOA).

A major finding of this study is that the hygroscopic material in $\beta$-caryophyllene SOA is semivolatile. The implications for CCN measurements are very important; the temperature at which $\mathrm{CCN}$ measurements are carried out, if the aerosol is volatile and composed of a low fraction of soluble material, may strongly bias the observed $\mathrm{CCN}$ activity. In our study, this bias shifted measured activation diameters between 25 and $30 \%$ and prevented $\mathrm{CCN}$ detection during the first half of the experiments. However, the bias can be identified and quantified if the aerosol is periodically passed through a thermodenuder, or, if $\mathrm{CCN}$ measurements are undertaken at different temperatures. The volatility of WSOC, if relevant SOA is formed in the atmosphere, carries important implications; since the temperature range in our measurements is typical of diurnal variations found during summertime conditions (where biogenic emissions and photochemical activity, hence SOA production, are maximum), volatilization of small amounts of aerosol may induce an unanticipated diurnal cycle of CCN activity.

The finding that the hygroscopic fraction is volatile (while the non-hygroscopic fraction is not) seems to contradict current thinking that oxidation reduces volatility (e.g. Duplissy et al., 2008); this certaintly applies if oxidation occurs through addition. Fragmentation however, could give oxidation products with lower molecular weight, which could increase both hygroscopicity and volatility. The latter is consistent with our findings, as the WSOC exhibits reduced average MW (compared to the parent hydrocarbon), and, volatility of the soluble fraction. Oligomerization may contribute the insoluble (less volatile) material, which could partially dissociate into (more volatile) monomers upon heating. Hydrolysis of the oligomers is also possible, which could contribute the soluble fraction. Future work should focus on which of the above applies, and, if the SOA exhibits the same characteristics under humidified conditions and lower parent hydrocarbon levels (Duplissy et al., 2008).

Another finding of this study is that the less volatile material in $\beta$-caryophyllene SOA is not very hygroscopic, but can impact droplet growth kinetics. The degree of kinetic limitations depend on the volume fraction of insoluble material in the SOA, as heating of the aerosol tends to decrease the droplet growth rates of the $\mathrm{CCN}$. We postulate this to be the result of soluble material evaporating from the surface of the SOA, potentially combined with redistribution (by melting) of "waxy" material to the CCN surface; both mechanisms would create a kinetic barrier that partially impedes water vapor condensation. An explicit relationship between the effective water vapor uptake coefficient (used here to represent variations in droplet growth kinetics) and WSOC fraction implies that one mechanism (that scales inversely with soluble volume fraction) is likely responsible for the observed growth delay, and, that it is from the presence of insoluble material. If this occurs in the atmosphere, the implications of these findings for cloud droplet formation are many: $i$ ) similar to CCN activity, a diurnal cycle of growth kinetics for biogenic aerosol may exist, with potentially important impacts on the droplet size distribution and aerosolcloud interactions, $i i$ ) the concept of "external mixing" may not be only important for CCN activity (i.e. $s_{c}$ ), but also for droplet growth kinetics, iii) evaporation of SOA in the dry, free troposphere could form particles that are kinetically limited, and, iv) SOA with high soluble fractions (e.g. monoterpene SOA) may grow as quickly as inorganic salt CCN (e.g. $\left(\mathrm{NH}_{4}\right)_{2} \mathrm{SO}_{4}$ ) (which is consistent with the limited data available to date, Engelhart et al. (2008)). Whether a simple relationship between $\alpha$ and $\varepsilon$ exists for lower parent hydrocarbon concentration or other SOA systems still remains to be found; the approach outlined in this study could be used to unravel and parameterize the complex relationship between volatility, $\mathrm{CCN}$ activity, growth kinetics and composition.

Acknowledgements. The work in this study was supported by an NSF CAREER (AN \& AAA), a NASA ESS Fellowship (AAA) and a Blanchard-Milliken Young Faculty Chair (AN). SNP acknowledges support by the EUCAARI European Union Project. The Carnegie Mellon University effort was supported by the US National Science Foundation (ATM-0336296). We would like to thank Gayle Hagler and Michael Bergin for use of their TOC Analyzer, Arsineh Hecobian for her aid with the IC Analysis in this study and Chris Ruehl for helpful comments.

Edited by: J. Seinfeld

\section{References}

An, W. J., Pathak, R. K., Lee, B. H., and Pandis, S. N.: Aerosol volatility measurement using an improved thermodenuder: Application to secondary organic aerosol, J. Aerosol Sci., 38, 305314, 2007.

Andreae, M. O. and Crutzen, P. J.: Atmospheric aerosols: Biogeochemical sources and role in atmospheric chemistry, Science, 276, 1052-1058, 1997.

Arey, J., Crowley, D. E., Crowley, M., Resketo, M., and Lester, J.: Hydrocarbon emissions from natural vegetation in California South-Coast-Air-Basin, Atmos. Environ., 29, 2977-2988, 1995.

Asa-Awuku, A. and Nenes, A.: The Effect of solute dissolution kinetics on cloud droplet formation: Extended Köhler Theory, J. Geophys. Res., 112, D22201, doi:10.1029/2005JD006 934, 2007.

Asa-Awuku, A., Nenes, A., Gao, S., Flagan, R. C., and Seinfeld, J. H.: Alkene ozonolysis SOA: inferences of composition and droplet growth kinetics from Köhler theory analysis, Atmos. Chem. Phys. Discuss., 7, 8983-9011, 2007, http://www.atmos-chem-phys-discuss.net/7/8983/2007/.

Asa-Awuku, A., Sullivan, A. P., Hennigan, C. J., Weber, R. J., and Nenes, A.: Investigation of molar volume and surfactant charac- 
teristics of water-soluble organic compounds in biomass burning aerosol, Atmos. Chem. Phys., 8, 799-812, 2008,

http://www.atmos-chem-phys.net/8/799/2008/.

Baltensperger, U., Kalberer, M., Dommen, J., Paulsen, D., Alfarra, M. R., Coe, H., Fisseha, R., Gascho, A., Gysel, M., Nyeki, S., Sax, M., Steinbacher, M., Prevot, A. S. H., Sjoren, S., Weingartner, E., and Zenobi, R.: Secondary organic aerosols from anthropogenic and biogenic precursors, Faraday Discuss., 130, 265-278, 2005.

Brechtel, F. J. and Kreidenweis, S. M.: Predicting particle critical supersaturation from hygroscopic growth measurements in the humidified TDMA. Part I: Theory and sensitivity studies, J. Aerosol Sci., 57(12), 1854-1871, 2000.

Cachier, H., Liousse, C., Buatmenard, P., and Gaudichet, A.: Particulate content of savanna fire emissions, J. Atmos. Chem., 22, 123-148, 1995.

Cai, X. Y. and Griffin, R. J.: Theoretical modeling of the sizedependent influence of surface tension on the absorptive partitioning of semi-volatile organic compounds, J. Atmos. Chem., 50, 139-158, 2005.

Calogirou, A., Kotzias, D., and Kettrup, A.: Product analysis of the gas-phase reaction of beta-caryophyllene with ozone, Atmos. Environ., 31, 283-285, 1997.

Ciccioli, P., Brancaleoni, E., Frattoni, M., Di Palo, V., Valentini, R., Tirone, G., Seufert, G., Bertin, N., Hansen, U., Csiky, O., Lenz, R., and Sharma, M.: Emission of reactive terpene compounds from orange orchards and their removal by within-canopy processes, J. Geophys. Res., 104, 8077-8094, 1999.

Conant, W., Vanreken, T., Rissman, T., Varutbangkul, V., Jimenez, J., Delia, A., Bahreini, R., C., R. G., Nenes, A., Jonsson, H., Flagan, R. C., and Seinfeld, J. H.: Aerosol-cloud drop concentration closure in warm cumulus, J. Geophys. Res., 109, D13204, doi:10.1029/2003JD004324, 2004.

Cruz, C. and Pandis, S. N.: A study of the ability of pure secondary organic aerosol to act as cloud condensation nuclei, Atmos. Environ., 31, 2205-2214, 1997.

Decesari, S., Facchini, M. C., Fuzzi, S., and Tagliavini, E.: Characterization of water-soluble organic compounds in atmospheric aerosol: A new approach, J. Geophys. Res., 105, 1481-1489, doi:10.1029/1999JD900950, 2000.

Decesari, S., Facchini, M. C., Mircea, M., Cavalli, F., and Fuzzi, S.: Solubility properties of surfactants in atmospheric aerosol and cloud/fog water samples, J. Geophys. Res., 108, 4685, doi:10. 1029/2003JD003566, 2003.

Dinar, E., Taraniuk, I., Graber, E. R., Katsman, S., Moise, T., Anttila, T., Mentel, T. F., and Rudich, Y.: Cloud Condensation Nuclei properties of model and atmospheric HULIS, Atmos. Chem. Phys., 6, 2465-2482, 2006,

http://www.atmos-chem-phys.net/6/2465/2006/.

Donahue, N. M., Huff-Hartz, K. E., Chuong, B., Presto, A. A., Stanier, C. O., Rosenørn, T., Robinson, A. L., and Pandis, S. N.: Critical factors determining the variation in SOA yields from terpene ozonolysis: A combined experimental and computational study, Faraday Discuss., 130, 295-309, 2005.

Duplissy, J., Gysel, M., Alfarra, M. R., Dommen, J., Metzger, A, Prevot, A. S. H., Weingartner, E., Laaksonen, A., Raatikainen, T., Good, N., Turner, S. F., McFiggans, G., and Baltensperger, U.: Cloud forming potential of secondary organic aerosol under near atmospheric conditions, Geophys. Res. Lett., 35, L03818,
doi:10.1029/2007GL031075, 2008.

Engelhart, G. J., Asa-Awuku, A., Nenes, A., and Pandis, S. N.: CCN activity and droplet growth kinetics of fresh and aged monoterpene secondary organic aerosol, Atmos. Chem. Phys., 8, 3937-3949, 2008,

http://www.atmos-chem-phys.net/8/3937/2008/.

Fletcher, C. A., Johnson, G. R., Ristovski, Z. D., and Harvey, M.: Hygroscopic and volatile properties of marine aerosol observed at Cape Grim during the P2P campaign, Environ. Chem., 4, 162 171, 2007.

Fountoukis, C. and Nenes, A.: Continued development of a cloud droplet formation parameterization for global climate models, J. Geophys. Res., 110, D11212, doi:10.1029/2004JD005591, 2005.

Fountoukis, C., Nenes, A., Meskhidze, N., Bahreini, R., Brechtel, F., Conant, W., Jonsson, H., Murphy, S., Sorooshian, A., Varutbangkul, V., Flagan, R., and Seinfeld, J.: Aerosol - cloud drop concentration closure for clouds sampled during ICARTT, J. Geophys. Res., 112, D10S30, doi:110.1029/2006JD007272, 2007.

Gerber, H. E., Hoppel, W. A., and Wojciechowski, T. A.: Experimental verification of the theoretical relationship between size and critical supersaturation of salt nuclei, J. Aerosol Sci., 34, 1836-1841, 1977.

Goldstein, A. H. and Galbally, I. E.: Known and unexplored organic constituents in the Earth's atmosphere, Environ. Sci. Technol., 41, 1514-1521, 2007.

Grieshop, A. P., Donahue, N. M., and Robinson, A. L.: Is the gas-particle partitioning in alpha-pinene secondary organic aerosol reversible?, Geophys. Res. Lett., 34, L14810, doi:10.1029/2007GL029987, 2007.

Griffin, R. J., Cocker, D. R., Flagan, R. C., and Seinfeld, J. H.: Organic aerosol formation from the oxidation of biogenic hydrocarbons, J. Geophys. Res., 104, 3555-3567, 1999a.

Griffin, R. J., Cocker, D. R., Seinfeld, J. H., and Dabdub, D.: Estimate of global atmospheric organic aerosol from oxidation of biogenic hydrocarbons, Geophys. Res. Lett., 26, 2721-2724, 1999b.

Grosjean, D., Williams, E. L., Grosjean, E., Andino, J. M., and Seinfeld, J. H.: Atmospheric oxidation of biogenic hydrocarbons - reaction of ozone with Beta-Pinene, D-Limonene and TransCaryophyllene, Environ. Sci. Technol., 27, 2754-2758, 1993.

Guenther, A., Hewitt, C. N., Erickson, D., Fall, R., Geron, C., Graedel, T., Harley, P., Klinger, L., Lerdau, M., McKay, W. A., Pierce, T., Scholes, B., Steinbrecher, R., Tallamraju, R., Taylor, J., and Zimmerman, P.: A Global-model of natural volatile organic-compound emissions, J. Geophys. Res., 100, 8873$8892,1995$.

Guenther, A., Archer, S., Greenberg, J., Harley, P., Helmig, D., Klinger, L., Vierling, L., Wildermuth, M., Zimmerman, P., and Zitzer, S.: Biogenic hydrocarbon emissions and landcover/climate change in a subtropical savanna, Phys. Chem. Earth., 24, 659-667, 1999.

Guenther, A., Geron, C., Pierce, T., Lamb, B., Harley, P., and Fall, R.: Natural emissions of non-methane volatile organic compounds; carbon monoxide, and oxides of nitrogen from North America, Atmos. Environ., 34, 2205-2230, 2000.

Hansen, U. and Seufert, G.: Temperature and light dependence of beta-caryophyllene emission rates, J. Geophys. Res., 108, 4801, doi:10.1029/2003JD003853, 2003. 
Helmig, D., Ortega, J., Duhl, T., Tanner, D., Guenther, A., Harley, P., Wiedinmyer, C., Milford, J., and Sakulyanontvittaya, T.: Sesquiterpene emissions from pine trees - Identifications, emission rates and flux estimates for the contiguous United States, Environ. Sci. Technol., 41, 1545-1553, 2007.

Henning, S., Rosenørn, T., D’Anna, B., Gola, A. A., Svenningsson, B., and Bilde, M.: Cloud droplet activation and surface tension of mixtures of slightly soluble organics and inorganic salt, Atmos. Chem. Phys., 5, 575-582, 2005, http://www.atmos-chem-phys.net/5/575/2005/.

Hoffmann, T.: Adsorptive preconcentration technique including oxidant scavenging for the measurement of reactive natural hydrocarbons in ambient air, Fresen. J. Anal. Chem., 351, 41-47, 1995.

Huff-Hartz, K. E., Rosenørn, T., Ferchak, S. R., Raymond, T. M., Bilde, M., Donahue, N. M., and Pandis, S. N.: Cloud condensation nuclei activation of monoterpene and sesquiterpene secondary organic aerosol, J. Geophys. Res., 110, D14208, doi: 10.1029/2004JD005754, 2005.

Jaoui, M., Leungsakul, S., and Kamens, R. M.: Gas and particle products distribution from the reaction of beta-caryophyllene with ozone, J. Atmos. Chem., 45, 261-287, 2003.

Jaoui, M., Lewandowski, M., Kleindienst, T. E., Offenberg, J. H., and Edney, E. O.: Beta-caryophyllinic acid: An atmospheric tracer for beta-caryophyllene secondary organic aerosol, Geophys. Res. Lett., 34, L05816, doi:10.1029/2006GL028827, 2007.

Johnson, G. R., Ristovski, Z. D., D'Anna, B., and Morawska, L.: Hygroscopic behavior of partially volatilized coastal marine aerosols using the volatilization and humidification tandem differential mobility analyzer technique, J. Geophys. Res., 110, d20203, doi:10.1029/2004JD005657, 2005.

Jonsson, A. M., Hallquist, M., and Saathoff, H.: Volatility of secondary organic aerosols from the ozone initiated oxidation of alpha-pinene and limonene, J. Aerosol Sci., 38, 843-852, 2007.

Kalberer, M.: Analysis of oligomers in atmospheric aerosol particles - analytical challenges, Anal. Bioanal. Chem., 385, 22-25, 2006.

Kalberer, M., Paulsen, D., Sax, M., Steinbacher, M., Dommen, J., Prevot, A. S. H., Fisseha, R., Weingartner, E., Frankevich, V., Zenobi, R., and Baltensperger, U.: Identification of polymers as major components of atmospheric organic aerosols, Science, 303, 1659-1662, 2004.

Kanakidou, M., Seinfeld, J. H., Pandis, S. N., Barnes, I., Dentener, F. J., Facchini, M. C., Van Dingenen, R., Ervens, B., Nenes, A., Nielsen, C. J., Swietlicki, E., Putaud, J. P., Balkanski, Y., Fuzzi, S., Horth, J., Moortgat, G. K., Winterhalter, R., Myhre, C. E. L., Tsigaridis, K., Vignati, E., Stephanou, E. G., and Wilson, J.: Organic aerosol and global climate modelling: a review, Atmos. Chem. Phys., 5, 1053-1123, 2005,

http://www.atmos-chem-phys.net/5/1053/2005/.

Kanawati, B., Herrmann, F., Joniec, S., Winterhalter, R., and Moortgat, G. K.: Mass spectrometric characterization of betacaryophyllene ozonolysis products in the aerosol studied using an electrospray triple quadrupole and time-of-flight analyzer hybrid system and density functional theory, Rapid Commun. Mass Spectrom., 22, 165-186, 2008.

Kleindienst, T. E., Jaoui, M., Lewandowski, M., Offenberg, J. H., Lewis, C. W., Bhave, P. V., and Edney, E. O.: Estimates of the contributions of biogenic and anthropogenic hydrocarbons to secondary organic aerosol at a southeastern US location, Atmos.
Environ., 41, 8288-8300, 2007.

Konig, G., Brunda, M., Puxbaum, H., Hewitt, C. N., Duckham, S. C., and Rudolph, J.: Relative contribution of oxygenated hydrocarbons to the total biogenic VOC emissions of selected MidEuropean agricultural and natural plant-species, Atmos. Environ., 29, 861-874, 1995.

Kostenidou, E., Pathak, R. K., and Pandis, S. N.: An algorithm for the calculation of secondary organic aerosol density combining AMS and SMPS data, Aerosol Sci. Technol., 41, 1002-1010, doi:10.1080/02786820701666270, 2007.

Kumar, P., Broekhuizen, K., and Abbatt, J. P. D.: Organic acids as cloud condensation nuclei: Laboratory studies of highly soluble and insoluble species, Atmos. Chem. Phys., 3, 509-520, 2003, http://www.atmos-chem-phys.net/3/509/2003/.

Lance, S., Nenes, A., and Rissman, T.: Chemical and dynamical effects on cloud droplet number: Implications for estimates of the aerosol indirect effect., J. Geophys. Res., 109, D22208, doi:10.1029/2004JD004596, 2004.

Lance, S., Medina, J., Smith, J. N., and Nenes, A.: Mapping the operation of the DMT Continuous Flow CCN counter, Aerosol Sci. Technol., 40, 242-254, 2006.

Lee, A., Goldstein, A. H., Keywood, M. D., Gao, S., Varutbangkul, V., Bahreini, R., Ng, N. L., Flagan, R. C., and Seinfeld, J. H.: Gas-phase products and secondary aerosol yields from the ozonolysis of ten different terpenes, J. Geophys. Res., 111, d07302, doi:10.1029/2006JD007050, 2006.

McFiggans, G., Artaxo, P., Baltensperger, U., Coe, H., Facchini, M. C., Feingold, G., Fuzzi, S., Gysel, M., Laaksonen, A., Lohmann, U., Mentel, T. F., Murphy, D. M., O'Dowd, C. D., Snider, J. R., and Weingartner, E.: The effect of physical and chemical aerosol properties on warm cloud droplet activation, Atmos. Chem. Phys., 6, 2593-2649, 2006, http://www.atmos-chem-phys.net/6/2593/2006/.

Meskhidze, N., Nenes, A., Conant, W., and Seinfeld, J. H.: Evaluation of a new cloud droplet activation parameterization with in-situ data from CRYSTAL-FACE and CSTRIPE, J. Geophys. Res., 110, D16202, doi:10.1029/2004JD005703, 2005.

Moore, R.H. Ingall, E., Sorooshian, A., and Nenes, A.: Molar mass, surface tension and droplet growth kinetics of marine organics from measurment of CCN activity, Geophys. Res. Lett., 35, L07801, doi:10.1029/2008GL033350, 2008.

Nenes, A. and Medina, J.: Scanning Mobility CCN Analysis - A method for fast measurements of size resolved $\mathrm{CCN}$ activity and growth kinetics, Aerosol Sci. Technol., in review, 2009.

Nenes, A., Chuang, P. Y., Flagan, R. C., and Seinfeld, J. H.: A theoretical analysis of cloud condensation nucleus $(\mathrm{CCN})$ instruments, J. Geophys. Res., 106, 3449-3474, doi:10.1029/ 2000JD900614, 2001.

Odum, J. R., Hoffmann, T., Bowman, F., Collins, D., Flagan, R. C., and Seinfeld, J. H.: Gas/particle partitioning and secondary organic aerosol yields, Environ. Sci. Technol., 30, 2580-2585, 1996.

Padró, L. T., Asa-Awuku, A., Morrison, R., and Nenes, A.: Inferring thermodynamic properties from $\mathrm{CCN}$ activation experiments: single-component and binary aerosols, Atmos. Chem. Phys., 7, 5263-5274, 2007, http://www.atmos-chem-phys.net/7/5263/2007/.

Pankow, J. F.: An absorption-model of gas-particle partitioning of organic-compounds in the atmosphere, Atmos. Environ., 28, 
185-188, 1994.

Parshintsev, J., Nurmi, J., Kilpelainen, I., Hartonen, K., Kulmala, M., and Riekkola, M. L.: Preparation of beta-caryophyllene oxidation products and their determination in ambient aerosol samples, Anal. Bioanal. Chem., 390, 913-919, 2008.

Pathak, R. K., Presto, A. A., Lane, T. E., Stanier, C. O., Donahue, N. M., and Pandis, S. N.: Ozonolysis of $\alpha$-pinene: parameterization of secondary organic aerosol mass fraction, Atmos. Chem. Phys., 7, 3811-3821, 2007,

http://www.atmos-chem-phys.net/7/3811/2007/.

Pöschl, U., Rudich, Y., and Ammann, M.: Kinetic model framework for aerosol and cloud surface chemistry and gas-particle interactions - Part 1: General equations, parameters, and terminology, Atmos. Chem. Phys., 7, 5989-6023, 2007, http://www.atmos-chem-phys.net/7/5989/2007/.

Prenni, A. J., Petters, M. D., Kreidenweis, S. M., DeMott, P. J., and Ziemann, P. J.: Cloud droplet activation of secondary organic aerosol, J. Geophys. Res., 112, d10223, doi:10.1029/ 2006JD007963, 2007.

Presto, A. A., Huff-Hartz, K. E., and Donahue, N. M.: Secondary organic aerosol production from terpene ozonolysis. 1. Effect of UV radiation, Environ. Sci. Technol., 39, 7036-4045, 2005a.

Presto, A. A., Huff-Hartz, K. E., and Donahue, N. M.: Secondary organic aerosol production from terpene ozonolysis. 2. Effect of NOx concentration, Environ. Sci. Technol., 39, 7046-7054, 2005 b.

Raymond, T. and Pandis, S. N.: Cloud activation of singlecomponent organic aerosol particles, J. Geophys. Res., 107, 4787, doi:10.1029/2002JD002159, 2002.

Reynolds, J. C., Last, D. J., McGillen, M., Nijs, A., Horn, A. B., Percival, C., Carpenter, L. J., and Lewis, A. C.: Structural analysis of oligomeric molecules formed from the reaction products of oleic acid ozonolysis, Environ. Sci. Technol., 40, 6674-6681, 2006.

Roberts, G. C. and Nenes, A.: A continuous-flow streamwise thermal-gradient $\mathrm{CCN}$ chamber for atmospheric measurements, Aerosol Sci. Technol., 39, 206-221, 2005.

Robinson, A. L., Donahue, N. M., Shrivastava, M. K., Weitkamp, E. A., Sage, A. M., Grieshop, A. P., Lane, T. E., Pierce, J. R., and Pandis, S. N.: Rethinking organic aerosols: Semivolatile emissions and photochemical aging, Science, 315, 1259-1262, 2007.

Rogge, W. F., Mazurek, M. A., Hildemann, L. M., Cass, G. R., and Simoneit, B. R. T.: Quantification of urban organic aerosols at a molecular-level - identification, abundance and seasonalvariation, Atmos. Environ., 27, 1309-1330, 1993.

Rose, D., Gunthe, S. S., Mikhailov, E., Frank, G. P., Dusek, U., Andreae, M. O., and Pöschl, U.: Calibration and measurement uncertainties of a continuous-flow cloud condensation nuclei counter (DMT-CCNC): CCN activation of ammonium sulfate and sodium chloride aerosol particles in theory and experiment, Atmos. Chem. Phys., 8, 1153-1179, 2008, http://www.atmos-chem-phys.net/8/1153/2008/.

Rudich, Y.: Laboratory perspectives on the chemical transformations of organic matter in atmospheric particles, Chem. Rev., 103, 5097-5124, 2003.

Ruehl, C. R., Chuang, P. Y., and Nenes, A.: How quickly do cloud droplets form on atmospheric particles?, Atmos. Chem. Phys., 8, 1043-1055, 2008,

http://www.atmos-chem-phys.net/8/1043/2008/.
Saathoff, H., Naumann, K. H., Schnaiter, M., Schock, W., Mohler, O., Schurath, U., Weingartner, E., Gysel, M., and Baltensperger, U.: Coating of soot and $\left(\mathrm{NH}_{4}\right)_{2} \mathrm{SO}_{4}$ particles by ozonolysis products of alpha-pinene, J. Aerosol Sci., 34, 1297-1321, 2003.

Saxena, P. and Hildemann, L. M.: Water-soluble organics in atmospheric particles: A critical review of the literature and application of thermodynamics to identify candidate compounds, J. Atmos. Chem., 24, 57-109, 1996.

Saxena, P., Hildemann, L. M., McMurry, P. H., and Seinfeld, J. H.: Organics alter hygroscopic behavior of atmospheric particles, J. Geophys. Res., 100, 18755-18770, 1995.

Seinfeld, J. H. and Pandis, S. N.: Atmospheric chemistry and physics: from air pollution to climate change, John Wiley, New York, 1998.

Seinfeld, J. H. and Pankow, J. F.: Organic atmospheric particulate material, An. Rev. Phys. Chem., 54, 121-140, 2003.

Shantz, N. C., Leaitch, W. R., and Caffrey, P.: Effect of organics of low solubility on the growth rate of cloud droplets., J. Geophys. Res., 108(D5), 4168, doi:10.1029/2002JD002540, 2003.

Shilling, J. E., King, S. M., Mochida, M., and Martin, S. T.: Mass spectral evidence that small changes in composition caused by oxidative aging processes alter aerosol CCN properties, J. Phys. Chem., 111, 3358-3368, 2007.

Shu, Y. G. and Atkinson, R.: Rate constants for the gas-phase reactions of $\mathrm{O}_{3}$ with a series of terpenes and $\mathrm{OH}$ radical formation from the $\mathrm{O}_{3}$ reactions with sesquiterpenes at $296 \pm 2^{\circ} \mathrm{K}$, Inter. J. Chem. Kinetics, 26, 1193-1205, 1994.

Shulman, M. L., Jacobson, M. C., Carlson, R. J., Synovec, R. E., and Young, T. E.: Dissolution behavior and surface tension effects of organic compounds in nucleating cloud droplets, Geophys. Res. Lett., 23, 277-280, doi:10.1029/95GL03810, 1996.

Stanier, C. O., Pathak, R. K., and Pandis, S. N.: Measurements of the volatility of aerosols from alpha-pinene ozonolysis, Environ. Sci. Technol., 41, 2756-2763, 2007.

Stroud, C., Nenes, A., Jimenez, J. L., DeCarlo, P. F., Huffman, J. A., Bruintjes, R., Nemitz, E., Delia, A. E., Toohey, D. W., Guenther, A. B., and Nandi, S.: Cloud activating properties of aerosol observed during CELTIC, J. Aerosol Sci., 64, 441-459, 2007.

Sullivan, A. P. and Weber, R. J.: Chemical characterization of the ambient organic aerosol soluble in water: 1 . Isolation of hydrophobic and hydrophilic fractions with a XAD-8 resin, J. Geophys. Res., 111, D05314, doi:10.1029/2005JD006485, 2006.

Sullivan, A. P., Weber, R. J., Clements, A. L., Turner, J. R., Bae, M. S., and Schauer, J. J.: A method for on-line measurement of water-soluble organic carbon in ambient aerosol particles: Results from an urban site, Geophys. Res. Lett., 31, 113105, doi:10.1029/2004GL019681, 2004.

Tomlinson, J. M., Li, R. J., and Collins, D. R.: Physical and chemical properties of the aerosol within the southeastern $\mathrm{Pa}$ cific marine boundary layer, J. Geophys. Res., 112, d12211, doi: 10.1029/2006JD007771, 2007.

VanReken, T. M., Ng, N. L., Flagan, R. C., and Seinfeld, J. H.: Cloud condensation nucleus activation properties of biogenic secondary organic aerosol, J. Geophys. Res., 110, d07206, doi: 10.1029/2004JD005465, 2005.

Varutbangkul, V., Brechtel, F. J., Bahreini, R., Ng, N. L., Keywood, M. D., Kroll, J. H., Flagan, R. C., Seinfeld, J. H., Lee, A., and Goldstein, A. H.: Hygroscopicity of secondary organic aerosols formed by oxidation of cycloalkenes, monoterpenes, sesquiter- 
penes, and related compounds, Atmos. Chem. Phys., 6, 23672388, 2006,

http://www.atmos-chem-phys.net/6/2367/2006/.

Virkkula, A., Van Dingenen, R., Raes, F., and Hjorth, J.: Hygroscopic properties of aerosol formed by oxidation of limonene, alpha-pinene, and beta-pinene, J. Geophys. Res., 104, 35693579, doi:10.1029/1998JD100017, 1999.

Volkamer, R., Jimenez, J. L., San Martini, F., Dzepina, K., Zhang, Q., Salcedo, D., Molina, L. T., Worsnop, D. R., and Molina, M. J.: Secondary organic aerosol formation from anthropogenic air pollution: Rapid and higher than expected, Geophys. Res. Lett., 33, 117811, doi:10.1029/2006GL026899, 2006.

Yamasoe, M. A., Artaxo, P., Miguel, A. H., and Allen, A. G.: Chemical composition of aerosol particles from direct emissions of vegetation fires in the Amazon Basin: water-soluble species and trace elements, Atmos. Environ., 34, 1641-1653, 2000.

Zappoli, S., Andracchio, A., Fuzzi, S., Facchini, M. C., Gelencser, A., Kiss, G., Krivacsy, Z., Molnar, A., Meszaros, E., Hansson, H. C., Rosman, K., and Zebuhr, Y.: Inorganic, organic and macromolecular components of fine aerosol in different areas of Europe in relation to their water solubility, Atmos. Environ., 33, 2733-2743, 1999.
Zhang, Q., Jimenez, J. L., Canagaratna, M. R., Allan, J. D., Coe, H., Ulbrich, I., Alfarra, M. R., Takami, A., Middlebrook, A. M., Sun, Y. L., Dzepina, K., Dunlea, E., Docherty, K., DeCarlo, P. F., Salcedo, D., Onasch, T., Jayne, J. T., Miyoshi, T., Shimono, A., Hatakeyama, S., Takegawa, N., Kondo, Y., Schneider, J., Drewnick, F., Borrmann, S., Weimer, S., Demerjian, K., Williams, P., Bower, K., Bahreini, R., Cottrell, L., Griffin, R. J., Rautiainen, J., Sun, J. Y., Zhang, Y. M., and Worsnop, D. R.: Ubiquity and dominance of oxygenated species in organic aerosols in anthropogenically-influenced Northern Hemisphere midlatitudes, Geophys. Res. Lett., 34, 113801, doi:10. 1029/2007GL029979, 2007.

Zhang, Q. H., Birgersson, G., Zhu, J. W., Lofstedt, C., Lofqvist, J., and Schlyter, F.: Leaf volatiles from nonhost deciduous trees: Variation by tree species, season and temperature, and electrophysiological activity in Ips typographus, J. Chem. Ecol., 25, 1923-1943, 1999. 